\title{
NUMBERS, DISTRIBUTION AND NEST SITE CHARACTERISTICS \\ OF JACKDAW Corvus monedula IN SLOVENIA AND ITS CONSERVATION STATUS
}

\section{Številčnost, razširjenost in značilnosti gnezdišč kavke Corvus monedula v Sloveniji ter njen varstveni status}

\section{LUKA BožIČ}

DOPPS - Društvo za opazovanje in proučevanje ptic Slovenije, Kamenškova 18, SI-2000 Maribor, Slovenija, e-mail: luka.bozic@dopps.si

In 2008, a coordinated census of Jackdaw Corvus monedula was carried out to assess breeding population, distribution and nest site selection in Slovenia. Data collection continued for unsurveyed areas in the 2009-2011 period, including information on former colonies and threats. A total of 663-794 Jackdaw pairs were recorded at 86 sites, while total Slovene breeding population was estimated to be in the range of 700-900 pairs. Over one third of pairs were recorded in Central Slovenia, notably the largest city Ljubljana (20.8\%), followed by almost a quarter in the Podravje region. Most colonies numbered between 2 and 5 pairs, the largest occupying the Bežigrad district of Ljubljana (82-87 pairs). Large-scale density in geographically more or less uniform areas ranged from 3.65 pairs $/ 10 \mathrm{~km}^{2}$ in the Sava plain to 0.15 pairs $/ 10 \mathrm{~km}^{2}$ in mostly mountainous area in northern Slovenia. The majority of Jackdaws selected buildings for nesting (82.2\% of pairs), while nesting in trees occurred less frequently (14.7\%) and was almost entirely confined to the two easternmost regions of Slovenia. Nesting in cliffs was recorded at just two sites in Slovene Istria (3.1\%). Average colony size differed significantly in relation to nest site type, with colonies in rock walls being on average the largest (median $=9.5$ pairs), followed by colonies on buildings (6) and those in trees the smallest (3). Among pairs nesting on buildings, multi-storey residential buildings predominated (34.2\%). A substantial percentage of population nested also on churches and tower blocks (14.4\% and $13.5 \%$, respectively). The highest percentage of pairs utilised holes in roofs (26.9\%), followed by eaves (18.0\%) and chimney pots (14.7\%). Tree-nesting pairs occupied mostly small woods situated in open agricultural landscape. The most commonly used tree species was Beech Fagus sylvatica ( $53.1 \%$ of pairs) which hosted 14 of the total 16 forest colonies. For Jackdaws nesting in urban parks and avenues, plane trees Platanus sp. were the most important (30.6\% of pairs). Their population stronghold was in lowlands, with $88.1 \%$ of pairs recorded at elevations under $400 \mathrm{~m}$ and the highest living colony in Slovenia at $578 \mathrm{~m}$ a.s.l. Jackdaws occurred on at least 54 specific sites in the past but became extinct there or declined severely by the time of this study. A minimum of 217-254 pairs were estimated lost at these sites, constituting a decline of $24 \%$ in c. $10-20$ years. According to the IUCN criteria, Jackdaw would qualify as Vulnerable (VU) on the Red List of Slovenia. The commonest known cause of extinction/decline is renovation of buildings, a threat that is projected to escalate in the near future.

Key words: Jackdaw, Corvus monedula, Slovenia, census, nest-site selection, conservation

Ključne besede: kavka, Corvus monedula, popis, izbira gnezdišč, varstvo 


\section{Introduction}

Jackdaw Corvus monedula is a sociable Corvidae species, widely distributed across large parts of Europe, extending into Central Asia as far as Lake Baikal, northern countries of the Middle East and the Maghreb. More than half of the global distribution lies in Europe where it is absent only from Iceland and the northern half of Fennoscandia (FraIssinet $e t$ al. I997, BirdLife InTERnATIONAL 2016). Molecular studies revealed that the species is only distantly related to other members of the group and some revised taxonomic classifications place it in a separate genus Coloeus. Currently, four subspecies are recognized (Del Hoyo et al. 2009, GiLl \& DonsKer 2016). C. $m$. spermologus breeds in all Central European countries including Slovenia, despite different statements in the past (e.g. Matvejev \& Vasić i 973, Cramp \& Perrins I994, OFFEREINS 2003).

Jackdaw is generally well studied, being a popular model species for numerous ethological studies, focused on research of various aspects of its complex social interactions, learning and instinctive behaviour (e.g. LORENZ 193 I, RÖEL 1978, SCHWAB et al. 2008, DAvidson et al. 2014, Kubitza et al. 2015). Also, many studies of breeding biology, nest site selection, breeding and foraging habitat characteristics and predation were carried out throughout Europe (ANTIKAINEN I980, i 987, Johnsson i 994, Soler \& Soler I993, Biondo I998, SAlVATi 2002A, Unger \& Peter 2002, ARNOLD \& GRIFFITHS 2003). Jackdaw is unique within genus Corvus by nesting in cavities, either natural or manmade. It is typically a colonial breeder with usually life-long pair-bonds, maintained throughout the year. Outside the breeding season Jackdaws are mostly gregarious and large communal roosts are characteristic (Cramp \& Perrins I 994).

The European breeding population is estimated at 8.4-15.8 million pairs, with highest numbers (good and medium quality estimates) in European Russia (2.4-5.5 m), Spain (1.5-2.7 m), the United Kingdom $(1.2-1.5 \mathrm{~m})$, Ireland $(814,000-2.0 \mathrm{~m})$ and Belarus (350,000-400,000). Except for Poland and Germany, figures in central European countries are much lower, typically a few thousand pairs. The overall European population trend in 1980-2014 was stable, although varying between countries, regions and shorter timeperiods. Large increases were reported from some important countries in NW Europe (e.g. Belgium, Finland, Sweden, UK). Trends in Central Europe were mixed with large long-term declines in the Czech Republic and Hungary and a stable population in Germany. However, populations increased in Austria,
Switzerland and Poland since 2000, while the species declined in Germany (BIRDLIFE INTERNATIONAL 20 I 5 , EBCC 2016). Relying on a rather vague population estimate given in the Ornithological Atlas of Slovenia (Ornitološki atlas Slovenije; data mostly collected throughout the 1980s) (GEISTER I995), the longterm trend in Slovenia was assessed as large decline (BIRDLIFE INTERNATIONAL 20I5).

Dedicated national surveys of its breeding populations and nest sites were carried out in Austria in 1993/94 (Dvorak 1996) and Switzerland in 1949/50, 1972-78 and 1989 (ZIMMERMANN I95I, Riggenbach 1979, Vogel 1990). Furthermore, results of several regional surveys from Austria and Germany were published (SCHMIDT 1988, MODEL I 996, RUDOLPH 2000, BRADER \& SAMHABER 2003, 2005, GSCHWANDTNER 2005, Hoi-LeitNer 2016). The only similar study from Slovenia was the regional census, carried out in 1998 on the Dravsko polje plain in NE Slovenia (Vogrin 1998). In early 1990s, Jackdaw was included in the study of cliff-nesting birds of the Kraški rob escarpment, SW Slovenia (MARČETA 1994). Apart from these, only a handful of short notes reporting on more interesting breeding season records is available (e.g. Perušek 1994, Štumberger 2003). As of the early 2000s, a reliable and up-to-date overview of Jackdaw numbers, distribution and nest sites in the country was non-existent.

This paper presents results of the first comprehensive Jackdaw census in Slovenia aimed to (1) produce reliable national and regional breeding population and density estimate(s), (2) improve knowledge of general and elevational distribution in the country, (3) obtain characteristics of nest sites, and (4) collect information on former colonies/nest sites and cause of extinction/ decline to allow a more profound evaluation of recent trend, potential threats and conservation status of the species.

\section{Methods}

\subsection{National census and breeding data collection}

In 2008, a coordinated country-wide census was launched. Generally, observers were invited to participate via DOPPS-BirdLife Slovenia web page, the journal Svet ptic and a specifically prepared leaflet. Special survey forms, instructions and maps were prepared. Areas where Jackdaws were expected to be widely distributed according to prior knowledge (Ljubljana, lowlands of Central Slovenia, part of the Podravje region) were divided into census plots and assigned to individual volunteer observers. Similarly, 
observers were allocated to all sites where Jackdaws were known to occur in the past or were suspected to occur. The census was implemented in two parts: the first between $1 \mathrm{Mar}$ and $15 \mathrm{Apr}$ aimed at locating breeding Jackdaws, the second between 1 May and 15 Jun aimed at surveying and mapping nest sites. Observers were advised to perform the census by midday to avoid effects of Jackdaw roosting aggregations which can also occur in the breeding season (CRAMP \& PERrINS I994, SCHMidT 1999B). Targeted data collection continued in the 2009-2011 period by means of (1) subsequent visits to unsurveyed plots, settlements and locations (requested or carried out by the author), (2) correspondence with experts/local ornithologists, (3) checking database entries at the Novi ornitološki atlas gnezdilk Slovenije (http://atlas.ptice.si; NOAGS), managed by DOPPS-BirdLife Slovenia and (4) considering available casual records.

Data collection was performed on two levels: (1) mandatory general section where information on location (as accurate as possible), date of observation, number of Jackdaws (pairs or individuals) and type of observation (breeding, foraging - observations of Jackdaws on the ground outside settlements or using urban open space, flying over - observed only flying and not seen landing) was required, and (2) detailed survey of nest sites.

\subsection{Nest site survey}

Basic nest site types (building, tree and cliff) were further divided into the following nest site subtypes: one- and two-storey residential building (1-2 levels), multistorey residential building (3-7 levels), tower block (>8 levels), church, castle, outbuilding (warehouse, stable, barn, silo etc.), industrial building (factory complexes etc.), continuous forest, isolated wood in open agricultural landscape, urban park or avenue, orchard, isolated tree (open country, outside urban areas), natural cliff and quarry. Recording the street/ road name and house number of buildings with nesting Jackdaws was required, and more precise description of the nest site encouraged (e.g. exact number of storeys, name of the building or area, etc.).

For detailed description of nest hole placement, i.e. kind of a nest hole used (not necessarily equal to nest as several pairs can access their nests through the same hole on the building and nests can be situated up to several metres from the entrance, e.g. in attics), the following categories were used: chimney pot, eaves (part of the roof projecting beyond the face of a wall), inner jutting roof (window corner or edge, balcony, vault etc.), wall, roof (between roof tiles or in the outer edge of the roof without eaves), tree hole, and area of damaged branch (cavity formed on the spot where branch was broken or cut off). Additionally, the height of the entrance hole above ground (all nest holes) and distance of nesting trees from the nearest forest edge (forest colonies only) was estimated and state of the building (actively used or abandoned) or species/genus of nesting tree were identified if possible.

The term location refers to the precise location of nesting Jackdaw pairs, either defined as an individual building of a given subtype, in most cases identifiable by its unique postal address (nest site type building; not necessarily identical to colony as these may extend over several different buildings), or colony/site mapped with accuracy within a few tens of metres (types tree and cliff).

\subsection{Former colonies and nest sites}

Information on breeding Jackdaws that existed prior to 2008 but were not recorded in this study was obtained by: (1) special section of the form used for the Jackdaw census, (2) correspondence with experts/ local ornithologists, (3) examination of forms filled in by volunteer observers in the "Bird of the Year 2000" (Ptica leta 2000) campaign (SMOLE 2000), (4) literature search, (5) NOAGS database. Data considered include location, year(s) of breeding (exact or estimated), source of information and number of pairs and cause of extinction, if known.

\subsection{Breeding pair and colony criteria}

All observations of Jackdaws on buildings and cliffs during the breeding season of the species (1 Mar-15 Jun) were treated as nest site records unless stated otherwise (e.g. specifically identified as non-breeders at that particular location by observers). For treenesters, the minimum EBCC breeding atlas code 6 (visiting probable nest site, HagemeIjer \& Blair 1997) was required. Except in cases when all nest holes of individual pairs were located, the number of pairs at a colony or site was determined by dividing the total number of Jackdaws by 2 . If the number of pairs early in the breeding season (1 Mar-31 Mar), broadly corresponding to pre-laying period, was higher than during the core season (1 Apr-15 Jun), or Jackdaws were not registered during the core season, the latter was regarded as minimum number and the former as maximum number of pairs. This assumption was used to account for the possibility of individuals prospecting potential nest sites but not actually nesting (cf. DAvidSon et al. 2014). Records of single individuals 
without observation details that indicated nesting were counted as $0-1$ pairs.

For records of Jackdaws merely seen foraging or flying over, number of pairs was determined in the same manner as for breeding observations only when the nearest known breeding locations were at least $5 \mathrm{~km}$ away. For observations at shorter distance, any supportive additional details (direction of flight, number of nesting pairs in surroundings, etc.) were taken into consideration to assess their breeding status. If not available, records were counted as $0-n$ pairs $(n=$ no. of individuals divided by 2).

Due to often difficult delineation of a colony in extensive, more or less uniformly built up areas in settlements with numerous Jackdaws, a cluster of nesting pairs was regarded to belong to a single colony if distances among them were $<500 \mathrm{~m}$. Pairs nesting farther away were treated as separate colony(-ies) (cf. Dvorak 1996). The term colony is used for nesting aggregations of two or more pairs. However, in calculations of average size of colonies solitary pairs were included.

\subsection{Statistics used}

The Anderson-Darling test was performed to determine whether data are normally distributed. Average values of normally distributed data were expressed as means \pm SD. Medians (more than 2 samples) were compared using the Kruskal-Wallis test (Fowler \& COHEN 1996). For graphical depiction of numerical data boxand-whiskers plots including data within 1.5 IQR were used. Percentages of pairs were calculated from median values of minimum and maximum number of pairs.

\section{Results}

\subsection{Numbers, distribution and breeding density}

According to the criteria used, a total of 663-794 pairs were recorded at 86 sites in Slovenia. At 62 of these, all or some of the actual breeding locations were ascertained, while at others birds were only observed foraging (13), flying over (7) or their breeding locations could not be found (4) (Table 1, Figure 1).

Table 1: Number of Jackdaw Corvus monedula pairs recorded during the Slovene country-wide census in 2008-2011. For non-urban records, name of the nearest settlement is given. GN - breeding, PREH - foraging, PREL - flyover.

Tabela 1: Števila parov kavke Corvus monedula, zabeležena v vsedržavnem popisu v Sloveniji v letih 2008-2011. Pri neurbanih podatkih je navedeno ime najbližjega naselja. GN - gnezdenje, PREH - prehranjevanje, PREL - prelet.

\begin{tabular}{|c|c|c|c|c|c|}
\hline \multirow[b]{2}{*}{ Settlement / Naselje } & \multirow{2}{*}{$\begin{array}{l}\text { Year of } \\
\text { observation/ } \\
\text { Leto } \\
\text { opazovanja }\end{array}$} & \multirow{2}{*}{$\begin{array}{l}\text { Type of } \\
\text { observation/ } \\
\text { Vrsta } \\
\text { opazovanja }\end{array}$} & \multicolumn{2}{|c|}{ No. of pairs / Št. parov } & \multirow{2}{*}{$\begin{array}{l}\text { No. of colonies } \\
\text { or solitary pairs/ } \\
\text { Št. kolonij oz. } \\
\text { posameznih parov }\end{array}$} \\
\hline & & & $\min$ & $\max$ & \\
\hline Ljubljana & 2008 & GN & 138 & 165 & $8^{*}$ \\
\hline Kranj & 2008 & GN & 59 & 64 & 3 \\
\hline Mirna na Dolenjskem & 2008 & GN & 59 & 59 & I \\
\hline Cirkovce & 2008 & GN & 25 & 31 & 2 \\
\hline Cerknica & 2008 & GN & 23 & 23 & I \\
\hline Grosuplje & 2008 & GN & 20 & 30 & $2^{*}$ \\
\hline Celje & 2008 & GN & 16 & 16 & I \\
\hline Bled & $2008-09$ & GN & 14 & 15 & 2 \\
\hline Trebnje & 2008 & PREH & 13 & 13 & Unkn. / Nez. \\
\hline Št. Jurij & 2008 & GN & I 2 & I2 & Unkn. / Nez. \\
\hline Beltinci & 2008 & GN & II & 17 & $3^{*}$ \\
\hline Serdica & 2008 & PREH & I I & I 2 & Unkn. / Nez. \\
\hline Vrhnika & 2008 & GN & II & I 2 & 2 \\
\hline Črenšovci & 2008 & GN & I I & I I & I \\
\hline Podpeč & 2009 & GN & II & I I & I \\
\hline Sveta Trojica & 2008 & GN & II & I I & I \\
\hline
\end{tabular}


Nadaljevanje tabele 1 / Continuation of Table 1

\begin{tabular}{|c|c|c|c|c|c|}
\hline \multirow[b]{2}{*}{ Settlement / Naselje } & \multirow{2}{*}{$\begin{array}{l}\text { Year of } \\
\text { observation/ } \\
\text { Leto } \\
\text { opazovanja }\end{array}$} & \multirow{2}{*}{$\begin{array}{l}\text { Type of } \\
\text { observation/ } \\
\text { Vrsta } \\
\text { opazovanja }\end{array}$} & \multicolumn{2}{|c|}{ No. of pairs / Št. parov } & \multirow{2}{*}{$\begin{array}{l}\text { No. of colonies } \\
\text { or solitary pairs/ } \\
\text { St. kolonij oz. } \\
\text { posameznih parov }\end{array}$} \\
\hline & & & $\min$ & $\max$ & \\
\hline Škofja Loka & 2008 & GN & II & II & $\mathrm{I}$ \\
\hline Zg. Jakobski dol & 2008 & GN & Io & 20 & $\mathrm{I}^{*}$ \\
\hline Pragersko & 2008 & GN & IO & II & I \\
\hline Adergas & 2010 & GN & 10 & Io & I \\
\hline Murska Sobota & 2008 & GN & 9 & 9 & 2 \\
\hline Drenov Grič & 2008 & GN & 8 & 8 & I \\
\hline Osp & 2009 & GN & 8 & 8 & I \\
\hline Logatec & 2008 & GN & 7 & 9 & I \\
\hline Ižakovci & 2008 & GN & 7 & 7 & I \\
\hline Jesenice & 2010 & GN & 7 & 7 & I \\
\hline Slovenj Gradec & 2009 & GN & 7 & 7 & Unkn. / Nez. \\
\hline Sv. Trije Kralji v Slovenskih goricah & 2008 & GN & 6 & 7 & I \\
\hline Škocjan & 2009 & GN & 6 & 6 & I \\
\hline Brežice & 2010 & GN & 5 & 6 & $I^{*}$ \\
\hline Dravograd & 2011 & GN & 5 & 5 & I \\
\hline Ptuj & 2008 & GN & 5 & 5 & I \\
\hline Šentilj v Slovenskih goricah & 2010 & GN & 5 & 5 & I \\
\hline Zg. Dražen vrh & 2008 & GN & 5 & 5 & $\mathrm{I}$ \\
\hline Zg. Hlapje & 2011 & GN & 5 & 5 & I \\
\hline Ciringa & 2008 & PREH & 4 & 15 & Unkn. / Nez. \\
\hline Lovrenc na Dravskem polju & 2008 & GN & 4 & 6 & I \\
\hline Gančani & 2008 & GN & 4 & 5 & $\mathrm{I}$ \\
\hline Jareninski dol & 2008 & GN & 4 & 4 & $\mathrm{I}$ \\
\hline Kočevje & 2009 & PREH & 4 & 4 & Unkn. / Nez. \\
\hline Lucija & 2008 & GN & 4 & 4 & I \\
\hline Sp. Hlapje & 2009 & GN & 4 & 4 & I \\
\hline Zdenska vas & 2008 & PREL & 4 & 4 & Unkn. / Nez. \\
\hline Rošpoh & 2008 & GN & 3 & 4 & I \\
\hline Flekušek & 2010 & GN & 3 & 3 & I \\
\hline Kotlje & 2008 & GN & 3 & 3 & I \\
\hline Počenik & 2008 & GN & 3 & 3 & I \\
\hline Šentjernej & 2008 & GN & 3 & 3 & I \\
\hline Ajdovščina & 2008 & PREH & 2 & 3 & Unkn. / Nez. \\
\hline Legen & 2009 & GN & 2 & 3 & I \\
\hline Tišina & 2010 & GN & 2 & 3 & I \\
\hline Begunje na Gorenjskem & 2010 & GN & 2 & 2 & $\mathrm{I}$ \\
\hline Breznica & 2010 & GN & 2 & 2 & I \\
\hline
\end{tabular}


Nadaljevanje tabele 1 / Continuation of Table 1

\begin{tabular}{|c|c|c|c|c|c|}
\hline \multirow[b]{2}{*}{ Settlement / Naselje } & \multirow{2}{*}{$\begin{array}{l}\text { Year of } \\
\text { observation/ } \\
\text { Leto } \\
\text { opazovanja }\end{array}$} & \multirow{2}{*}{$\begin{array}{l}\text { Type of } \\
\text { observation/ } \\
\text { Vrsta } \\
\text { opazovanja }\end{array}$} & \multicolumn{2}{|c|}{ No. of pairs / Št. parov } & \multirow{2}{*}{$\begin{array}{l}\text { No. of colonies } \\
\text { or solitary pairs/ } \\
\text { Št. kolonij oz. } \\
\text { posameznih parov }\end{array}$} \\
\hline & & & $\min$ & $\max$ & \\
\hline Cirknica & 2008 & GN & 2 & 2 & I \\
\hline Dragonja vas & 2008 & GN & 2 & 2 & $\mathrm{I}^{* *}$ \\
\hline Krško & 2008 & GN & 2 & 2 & I \\
\hline Lendava & 2010 & GN & 2 & 2 & I \\
\hline Mala vas pri Grosupljem & 2008 & $\mathrm{GN}$ & 2 & 2 & Unkn. / Nez. \\
\hline Mihovce & 2008 & GN & 2 & 2 & $\mathrm{I}^{* *}$ \\
\hline Ormož & 2011 & $\mathrm{GN}$ & 2 & 2 & I \\
\hline Slatinski Dol & 2010 & GN & 2 & 2 & I \\
\hline Budinci & 2008 & GN & I & 2 & I \\
\hline Šmarjeta & 2009 & GN & I & 2 & I \\
\hline Brezula & 2008 & GN & I & I & I \\
\hline Gačnik & 2008 & GN & I & I & I \\
\hline Pertoča & 2010 & PREH & I & I & Unkn. / Nez. \\
\hline Rakičan & 2008 & $\mathrm{GN}$ & I & I & I \\
\hline Sotina & 2008 & GN & I & I & I \\
\hline Sp. Gaj pri Pragerskem & 2008 & GN & I & I & Unkn. / Nez. \\
\hline Vuhred & 2008 & PREH & I & I & Unkn. / Nez. \\
\hline Dražen vrh & 2008 & PREH & $\circ$ & 8 & Unkn. / Nez. \\
\hline Jarenina & 2008 & PREH & $\circ$ & 8 & Unkn. / Nez. \\
\hline Jurski vrh & 2008 & PREH & $\circ$ & 8 & Unkn. / Nez. \\
\hline Podova & 2008 & GN & $\circ$ & 3 & I \\
\hline Brezovica pri Ljubljani & 2009 & PREL & $\circ$ & I & Unkn. / Nez. \\
\hline Črna vas & 2010 & GN & $\circ$ & I & I \\
\hline Dobrava, Izola & 2008 & PREL & $\circ$ & I & Unkn. / Nez. \\
\hline Dolenci & 2008 & PREH & ○ & I & Unkn. / Nez. \\
\hline Izola & 2009 & PREL & $\circ$ & I & Unkn. / Nez. \\
\hline Koper & 2008 & PREL & $\circ$ & I & Unkn. / Nez. \\
\hline Log pri Brezovici & 2009 & PREH & $\circ$ & I & Unkn. / Nez. \\
\hline Pleterje & 2008 & GN & $\circ$ & I & I \\
\hline Seča & 2011 & $\mathrm{GN}$ & $\circ$ & I & I \\
\hline Slovenja vas & 2011 & PREL & $\circ$ & I & Unkn. / Nez. \\
\hline Slovenska Bistrica & 2008 & PREL & $\circ$ & I & Unkn. / Nez. \\
\hline Velika Ligojna & 2009 & PREH & 0 & I & Unkn. / Nez. \\
\hline Total / Skupaj & & & 663 & 794 & $77^{*}$ \\
\hline
\end{tabular}

Certainly (or most probably) not all colonies were found. / Zanesljivo oziroma verjetno niso bile odkrite vse kolonije.

According to the applied criteria, pairs belong to the same colony. / Glede na uporabljene kriterije pari pripadajo isti koloniji. Unkn. / Nez. (Unknown / Neznano) - No. of colonies is unknown or breeding locations could not be found. / Št. kolonij ni znano oziroma gnezditvene lokacije niso bile odkrite. 
Over one third of pairs were recorded in Central Slovenia, notably the largest city Ljubljana (20.8\%), followed by almost a quarter in Podravje. Large local populations were also registered in Gorenjska $(14.8 \%)$ and Southeast Slovenia (12.4\%). Although present in all main regions of the country, numbers in the Northern Primorska region were very small and breeding remained unconfirmed there (Table 2). Jackdaw pairs with known locations (580-626, 82.8\% of the total) were breeding in 70 colonies and seven solitary-pair sites. Most colonies held between 2 and 5 pairs (Figures 2, 3). The largest colonies were in the Bežigrad district of Ljubljana (82-87 pairs), prison buildings at Mirna na Dolenjskem (59 pairs) and the Planina housing district of Kranj (40 pairs).

Breeding density varied markedly among UTM $10 \times 10 \mathrm{~km}$ squares. In a square covering urban areas of Ljubljana, it reached 147 pairs $/ 100 \mathrm{~km}^{2}$.
In predominantly rural areas, the highest densities exceeded 50 pairs $/ 100 \mathrm{~km}^{2}$, but were mostly well below that value $\left(<10\right.$ pair/100 $\left.\mathrm{km}^{2}\right)$ (Figure 4). Large-scale density in geographically more or less uniform areas ranged from 3.65 pairs $/ 10 \mathrm{~km}^{2}$ in the Sava plain to 0.15 pairs $/ 10 \mathrm{~km}^{2}$ in mostly mountainous area in northern Slovenia. Density of Jackdaws breeding in city centres reached 24.6 and 15.6 pairs $/ 10 \mathrm{~km}^{2}$ in Kranj and Ljubljana, respectively (Table 3 ).

\subsection{Nest site types and subtypes}

The majority of Jackdaws with known breeding locations selected buildings ( $82.2 \%$ of pairs), while nesting in trees occurred less frequently (14.7\%) and was almost entirely confined to the two easternmost regions of Slovenia. In Prekmurje and Podravje, 69.2 and $40 \%$ of regional breeding pairs were tree-nesters,

Figure 1: Distribution of settlements/sites with Jackdaws Corvus monedula in Slovenia in 2008-2011 ( $N=86)$. Size of the circle corresponds to the number of pairs (max) recorded.

Slika 1: Razširjenost naselij/krajev s kavkami Corvus monedula v Sloveniji v letih 2008-2011 ( $N=86$ ). Velikost kroga ustreza številu zabeleženih parov (max).

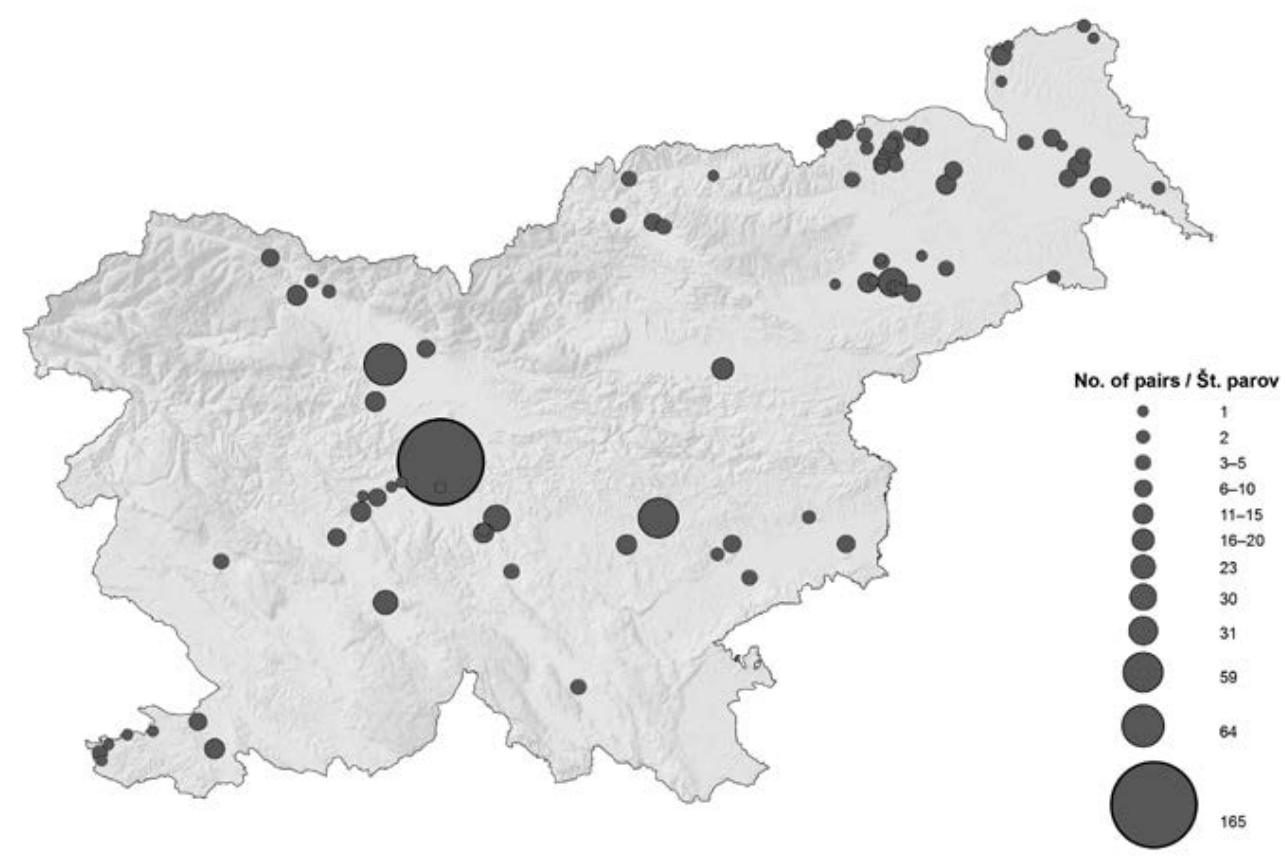


Table 2: Number and percentage of Jackdaw Corvus monedula pairs in macroregions (bold) and mesoregions of Slovenia in 2008-2011. Regionalisation according to PLUT (1999).

Tabela 2: Števila in odstotki parov kavke Corvus monedula v makroregijah (krepko) in mezoregijah Slovenije v letih 20082011. Regionalizacija je povzeta po PLuTu (1999).

\begin{tabular}{|c|c|c|c|c|}
\hline \multirow[b]{2}{*}{ Macroregion / Makroregija } & \multirow[b]{2}{*}{ Mesoregion / Mezoregija } & \multicolumn{2}{|c|}{ No. of pairs / Št. parov } & \multirow{2}{*}{$\begin{array}{l}\text { Percentage of pairs/ } \\
\text { Odstotek parov (\%) }\end{array}$} \\
\hline & & $\min$ & $\max$ & \\
\hline Pomurje & Prekmurje & $6 \mathrm{I}$ & 72 & 9.1 \\
\hline \multirow[t]{5}{*}{ Podravje } & & 138 & 201 & $23 \cdot 3$ \\
\hline & Spodnje Podravje & 40 & 50 & 6.2 \\
\hline & Mariborska & 69 & II9 & I 2.9 \\
\hline & Dravinjska & II & 13 & I.6 \\
\hline & Koroška & 18 & 19 & 2.5 \\
\hline Savinjska Slovenija & Celjska & 16 & 16 & 2.2 \\
\hline \multirow[t]{3}{*}{ JV Slovenija } & & 89 & $9 \mathrm{I}$ & I 2.4 \\
\hline & Spodnje Posavje & 7 & 8 & I.O \\
\hline & Srednja Dolenjska & 82 & 83 & II.3 \\
\hline \multirow[t]{4}{*}{ Osrednja Slovenija } & & 229 & 273 & 34.5 \\
\hline & Ljubljanska & 202 & 246 & 30.7 \\
\hline & Kočevsko-ribniška & 4 & 4 & 0.5 \\
\hline & Notranjska & 23 & 23 & 3.2 \\
\hline \multirow[t]{4}{*}{ Gorenjska } & & 105 & III & I 4.8 \\
\hline & Srednja Gorenjska & 69 & 74 & 9.8 \\
\hline & Škofjeloška & II & II & 1.5 \\
\hline & Zgornja Gorenjska & 25 & 26 & 3.6 \\
\hline S Primorska & Goriška & 2 & 3 & 0.3 \\
\hline J Primorska & Slovenska Istra & 23 & 27 & 3.4 \\
\hline Total / Skupaj & & 663 & 794 & 100.0 \\
\hline
\end{tabular}

respectively. Nesting in cliffs was recorded at just two sites in Slovene Istria, accounting for 3.1\% of national population (Table 4, Figure 5). Forty-nine colonies and four solitary pairs were nesting on buildings, and 19 colonies and three solitary pairs on trees (Figure 3). Average colony size differed significantly in relation to nest site type (Kruskal-Wallis test, $H=8.784$, $\mathrm{df}=2, P=0.012$ ), with colonies in cliffs being on average the largest $($ median $=9.5$ pairs, range $=8-11$ pairs), followed by colonies on buildings (median $=6$, range $=1-87$ ) and those in trees the smallest (median $=3$, range $=1-7)($ Figure 6$)$.

Most pairs nesting on buildings used multi-storey residential buildings (34.2\% of pairs). A substantial percentage of population nested also on churches and tower blocks (14.4\% and $13.5 \%$, respectively), the latter being limited mostly to cities and towns of Central
Slovenia. Nesting on one- and two-storey residential buildings predominated in parts of the Podravje region. Castles, outbuildings, industrial buildings and electric transformer stations proved to be of low importance for nesting Jackdaws in Slovenia (Table 4, Figure 7). There was a highly significant difference in average number of nesting pairs between main building types used (Kruskal-Wallis test, $H=25.884, \mathrm{df}=5, P<0.0001$ ). On average, the highest number of pairs nested on tower blocks and churches (median $=4$, range 1-15 and 1-11, respectively) and the lowest on one-storey residential buildings (median $=1$, range 1-2) (Figure 8). Most of them were in active use (96.5\%).

Tree-nesting pairs occupied mostly small woods situated in open agricultural landscape (mean surface area $=7.7 \pm 4.51$ ha, range $=1.0-19.6$ ha). Apart from three separate pairs that were obviously part of larger 


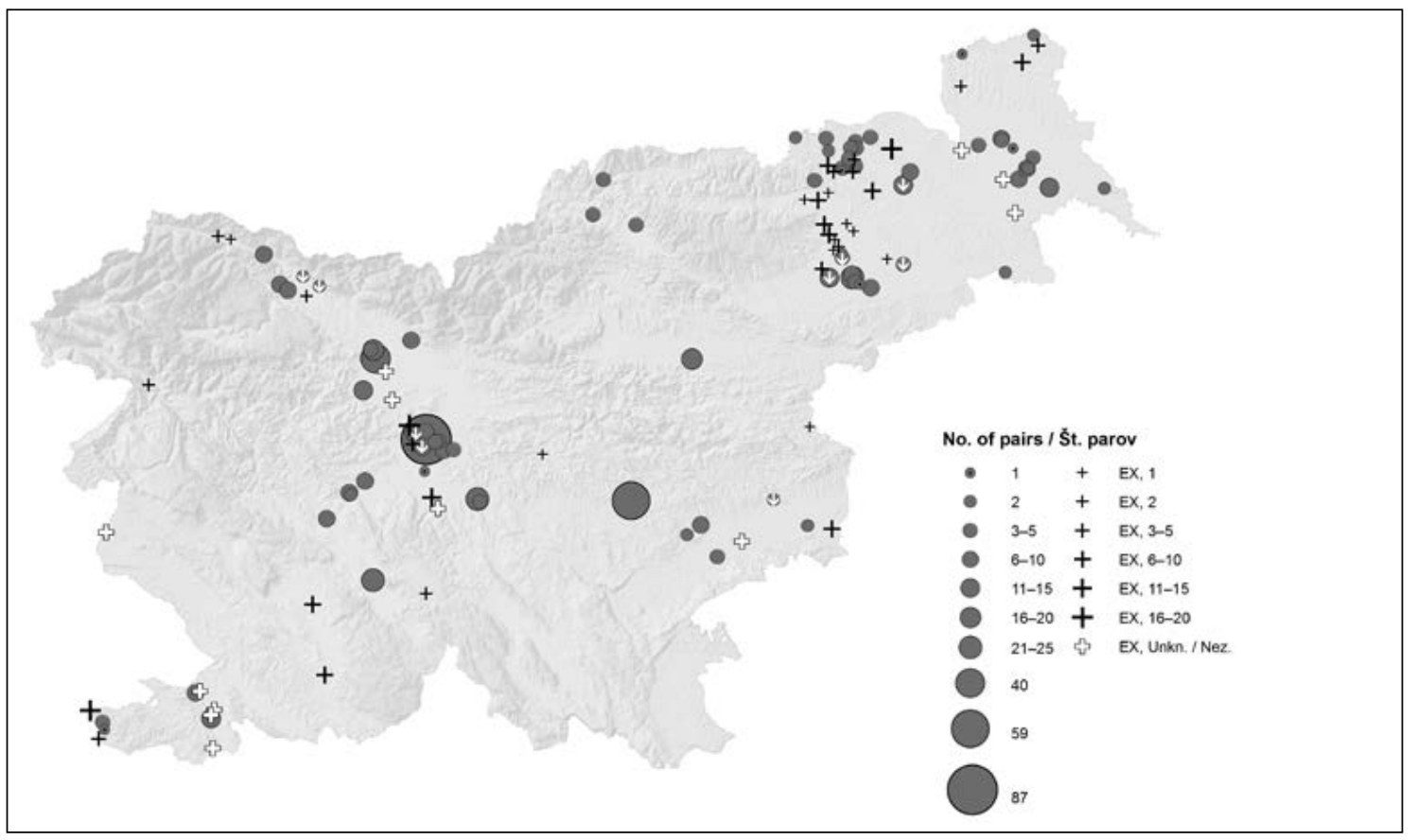

Figure 2: Jackdaw Corvus monedula colonies and solitary pairs in Slovenia in 2008-2011: circles depict distribution during this study $(\mathrm{N}=77)$, while crosses denote pairs at sites known prior to 2008 but not recorded later on, i.e. extinct $(\mathrm{N}=45)$. Downward arrow indicates colonies reduced by $>20 \%$. Size of the symbol corresponds to the number of pairs (max, white cross $=$ no. unknown).

Slika 2: Kolonije in posamezni pari kavk Corvus monedula v Sloveniji v letih 2008-2011: krogi ponazarjajo razširjenost $v$ tej raziskavi $(N=77)$, križi pa pare na krajih, znanih pred letom 2008, ki kasneje niso bili zabeleženi in so torej izumrli $(\mathrm{N}=45)$. Navzdol obrnjena puščica označuje kolonije, zmanjšane za $>20 \%$. Velikost simbola ustreza številu parov (max, beli križ = št. neznano).

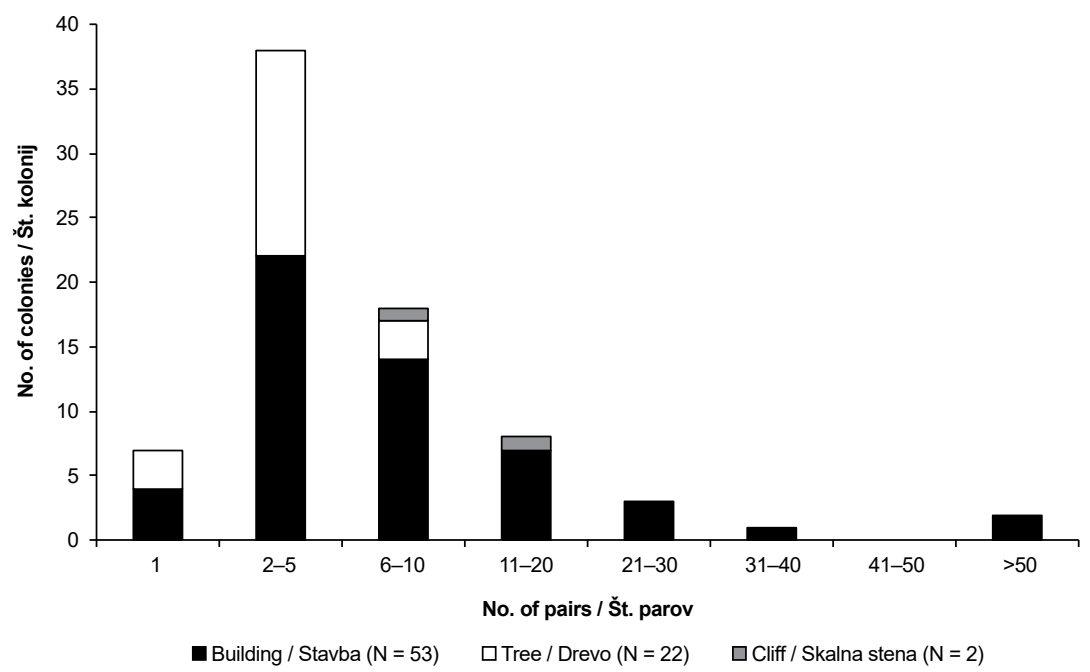

Figure 3: Number of Jackdaw Corvus monedula colonies/solitary pairs ( $N=77$ ) in Slovenia in 2008-2011 in different size classes (max. no. of pairs), depicted separately by nest site types

Slika 3: Število kolonij/posameznih parov kavke Corvus monedula $(\mathrm{N}=77)$ v Sloveniji v letih 2008-2011 v različnih velikostnih razredih (max. št. parov), prikazano ločeno po tipih gnezdišč 
Table 3: Breeding density of Jackdaw Corvus monedula in regions with records from at least five sites, and three largest cities of Slovenia in 2008-2011. No. of pairs and surface areas are given. Regions are partly modified from PERKO \& OROžEN ADAMIČ (1999).

Tabela 3: Gnezditvena gostota kavke Corvus monedula v regijah s podatki iz vsaj petih krajev in treh največjih mestih Slovenije v letih 2008-2011. Podana sta število parov in površina. Regije so delno spremenjene povzete po PERKU \& ORožEN ADAMIČU (1999).

\begin{tabular}{|c|c|c|c|c|c|}
\hline \multirow[b]{2}{*}{ Region, city or town / Regija, mesto } & \multirow{2}{*}{$\begin{array}{l}\text { Area/ } \\
\text { Površina }\left(\mathrm{km}^{2}\right)\end{array}$} & \multicolumn{2}{|c|}{ No. of pairs / Št. parov } & \multicolumn{2}{|c|}{ Density / Gostota $\left(\mathrm{p} / \mathrm{s} \circ \mathrm{km}^{2}\right)$} \\
\hline & & $\min$ & $\max$ & $\min$ & $\max$ \\
\hline Goričko & 492 & I4 & 17 & 0.28 & 0.35 \\
\hline Murska ravan & 601 & 52 & 66 & 0.87 & I.IO \\
\hline Slovenske gorice & 1034 & 47 & 55 & 0.45 & 0.53 \\
\hline Dravska ravan & 425 & 68 & IIS & 1.60 & $2.7 \mathrm{I}$ \\
\hline Strojna, Kozjak in Pohorje & I 287 & I 8 & 19 & 0.14 & 0.15 \\
\hline Savska ravan & 676 & 243 & 276 & 3.59 & 4.08 \\
\hline Ljubljansko barje & 180 & 19 & 24 & 1.06 & 1.33 \\
\hline Dolenjsko podolje & 318 & 106 & II 6 & $3 \cdot 33$ & 3.65 \\
\hline Krška ravan in gričevje & 520 & 17 & 19 & 0.33 & 0.37 \\
\hline Koprska brda & 326 & 23 & 27 & $0.7 \mathrm{I}$ & 0.83 \\
\hline Ljubljana & 106 & 138 & 165 & 13.02 & 15.57 \\
\hline Celje & 23 & 16 & 16 & 6.96 & 6.96 \\
\hline Kranj & 26 & 59 & 64 & 22.69 & 24.62 \\
\hline
\end{tabular}

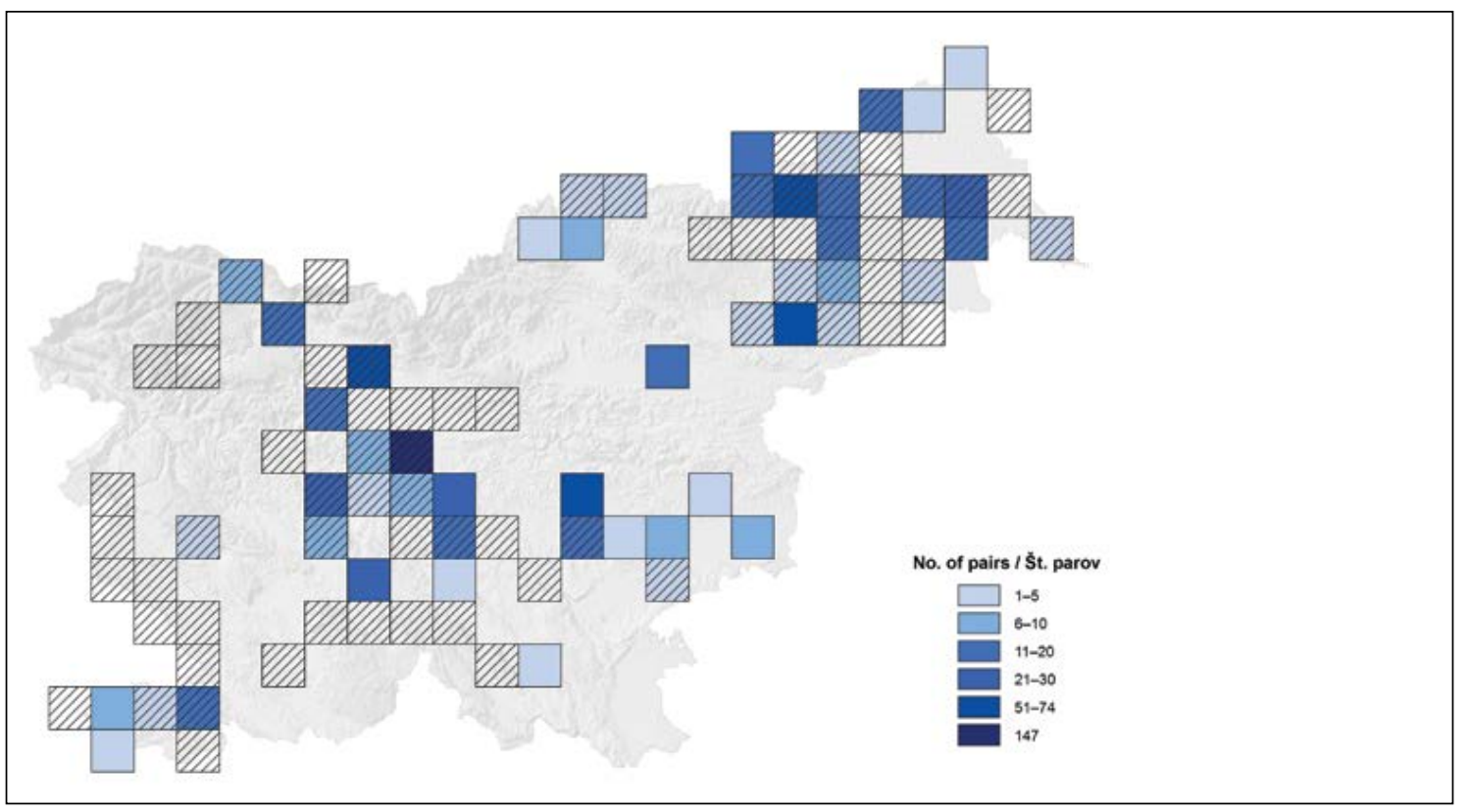

Figure 4: Number of Jackdaw Corvus monedula pairs (max) in UTM $10 \mathrm{~km}$ squares of Slovenia during this study ( $\mathrm{N}=51$ squares) and distribution given in the Ornithological Atlas of Slovenia (GEISTER 1995) (hatched, $N=74$ squares)

Slika 4: Števila parov kavke Corvus monedula (max) v UTM kvadratih Slovenije $10 \times 10 \mathrm{~km}$ v tej raziskavi (N = 51 kvadratov) in razširjenost v Ornitološkem atlasu gnezdilk Slovenije (GEISTER 1995) (šrafura, N = 74 kvadratov) 
Table 4: Nest site types (bold) and subtypes of Jackdaws Corvus monedula ( $N=585-641$ pairs) in Slovenia in 20082011. No. of locations ( $N=170$ ) is either number of individual buildings of a given subtype used by nesting pairs (type building) or number of colonies/sites per individual subtype (types tree and cliff).

Tabela 4: Tipi (krepko) in podtipi gnezdišč kavke Corvus monedula ( $N=585-641$ parov) v Sloveniji v letih $2008-2011$. Št. lokacij ( $N=170)$ je bodisi število posameznih stavb določenega podtipa, ki so ga uporabljali gnezdeči pari (tip stavba), bodisi število kolonij/krajev na posamezen podtip (tipa drevo in skalna stena).

\begin{tabular}{|c|c|c|c|c|c|}
\hline \multirow{2}{*}{$\begin{array}{l}\text { Nest site type and subtype / Tip in podtip } \\
\text { gnezdišča }\end{array}$} & \multirow{2}{*}{$\begin{array}{l}\text { No. of } \\
\text { locations/ } \\
\text { Št. lokacij }\end{array}$} & \multirow{2}{*}{$\begin{array}{l}\text { Percentage } \\
\text { of locations/ } \\
\text { Odstotek } \\
\text { lokacij (\%) }\end{array}$} & \multicolumn{2}{|c|}{ No. of pairs / Št. parov } & \multirow{2}{*}{$\begin{array}{l}\text { Percentage } \\
\text { of pairs/ } \\
\text { Odstotek } \\
\text { parov (\%) }\end{array}$} \\
\hline & & & $\min$ & $\max$ & \\
\hline $\begin{array}{l}\text { One-storey residential building / Enonadstropna } \\
\text { stanovanjska hiša }\end{array}$ & 13 & 7.6 & II & I 4 & 2.0 \\
\hline $\begin{array}{l}\text { Two-storey residential building / Dvonadstropna } \\
\text { stanovanjska hiša }\end{array}$ & 26 & $15 \cdot 3$ & 39 & 52 & $7 \cdot 4$ \\
\hline $\begin{array}{l}\text { Multi-storey residential building / } \\
\text { Večnadstropna stanovanjska hiša }\end{array}$ & 54 & 31.8 & 205 & 214 & 34.2 \\
\hline Tower block / Stolpnica & 16 & 9.4 & $8 \mathrm{I}$ & 84 & 13.5 \\
\hline Church / Cerkev & 18 & 10.6 & 85 & 92 & I 4.4 \\
\hline Castle / Grad & I & 0.6 & 2 & 2 & 0.3 \\
\hline Outbuilding / Gospodarsko poslopje & 2 & $\mathrm{I} .2$ & 2 & 3 & 0.4 \\
\hline Industrial building / Industrijski objekt & 3 & I.8 & 7 & 9 & 1.3 \\
\hline Other / Drugo & 9 & $5 \cdot 3$ & 34 & 38 & 5.9 \\
\hline Unknown / Neznano & - & - & 17 & 17 & 2.8 \\
\hline Building / Stavba & 142 & 83.5 & 483 & 525 & 82.2 \\
\hline Continuous forest / Sklenjen gozd & 2 & 1.2 & 8 & 8 & 1.3 \\
\hline $\begin{array}{l}\text { Isolated wood in open agricultural landscape / } \\
\text { Izoliran gozdiček v odprti kmetijski krajini }\end{array}$ & I 4 & 8.2 & 50 & 51 & 8.2 \\
\hline Urban park or avenue / Park, drevored & 9 & $5 \cdot 3$ & 20 & 22 & 3.4 \\
\hline Orchard / Sadovnjak & I & 0.6 & $\circ$ & I & O.I \\
\hline Unknown / Neznano & - & - & 5 & 15 & I.6 \\
\hline Tree / Drevo & 26 & 15.3 & 83 & 97 & 14.7 \\
\hline Natural cliff / Naravna skalna stena & 2 & 1.2 & 19 & 19 & 3.1 \\
\hline Cliff / Skalna stena & 2 & 1.2 & 19 & 19 & 3.1 \\
\hline
\end{tabular}

building-nesting colonies, nesting in urban parks and avenues was only registered in the lowland part of Prekmurje (Table 4, Figure 5).

\subsection{Nest hole placement characteristics}

All of the reported certain or presumed Jackdaw nests (441-465 pairs, $62.2 \%$ of the total) were placed in cavities, i.e. different types of nest holes. The highest percentage of pairs utilised holes in the roof (26.9\%), even though this nest hole type was only used at eight locations, followed by eaves (18.0\%) and chimney pots (14.7\%) (Table 5, Figure 9).
In tree-nesting pairs, the selection of tree holes predominated strongly ( $>90 \%$ of tree-nesting pairs). The most commonly used tree species was Beech Fagus sylvatica ( $53.1 \%$ of pairs) which hosted 14 of total 16 forest colonies/solitary pairs. Average distance of nesting trees of forest colonies from the nearest forest edge was $32 \pm 19.7 \mathrm{~m}$ (range $0-65 \mathrm{~m}$ ). The highest percentage $(30.6 \%)$ of pairs in urban parks and avenues nested in plane trees Platanus sp. All exclusively treenesting colonies (6) in urban areas used trees of this genus (Table 6, Figure 10).

Both cliff-nesting colonies used natural crevices in steep rocky faces. 
Estimated height of nest holes above ground varied strongly, resulting in highly significant difference in average height of Jackdaw nests between main nest site subtypes (Kruskal-Wallis test, $H=116.514, \mathrm{df}=7$, $P<0.0001$ ) (Figure 11).

\subsection{Elevational distribution}

Breeding Jackdaws were found from sea level to lower submontane elevation belt. Population stronghold is in lowlands, with $88.1 \%$ of pairs recorded at elevations

Table 5: Nest hole placement of Jackdaws Corvus monedula ( $\mathrm{N}=441-465$ pairs) and their percentage in Slovenia in 2008-2011. No. of locations ( $N=127$ ) is either number of individual buildings (type building) or number of colonies/sites (types tree and cliff) with a given nest placement recorded.

Tabela 5: Meșta gnezdilnih lukenj kavk Corvus monedula ( $N=441-465$ parov) in njihovi odstotki v Sloveniji v letih 2008-2011. Št. lokacij $(N=127)$ je število posameznih stavb (tip stavba) ali število kolonij/krajev (tipa drevo in skalna stena) z določenim mestom gnezdenja.

\begin{tabular}{|c|c|c|c|c|c|}
\hline \multirow{2}{*}{$\begin{array}{l}\text { Nest hole placement / Mesto gnezdilne } \\
\text { luknje }\end{array}$} & \multirow{2}{*}{$\begin{array}{l}\text { No. of } \\
\text { locations/ } \\
\text { Št. lokacij }\end{array}$} & \multirow{2}{*}{$\begin{array}{l}\text { Percentage } \\
\text { of locations/ } \\
\text { Odstotek } \\
\text { lokacij }(\%)\end{array}$} & \multicolumn{2}{|c|}{ No. of pairs / Št. parov } & \multirow{2}{*}{$\begin{array}{l}\text { Percentage } \\
\text { of pairs/ } \\
\text { Odstotek } \\
\text { parov (\%) }\end{array}$} \\
\hline & & & $\min$ & $\max$ & \\
\hline Chimney pot / Dimnik & 38 & 29.9 & 62 & $7 \mathrm{I}$ & 14.7 \\
\hline Eaves / Napušč & $3 \mathrm{I}$ & 24.4 & 78 & 85 & I8.0 \\
\hline Inner jutting roof / Notranji nadstrešek & 8 & 6.3 & 33 & 37 & $7 \cdot 7$ \\
\hline Wall / stena & Io & $7 \cdot 9$ & 55 & 57 & $\mathrm{I} 2.4$ \\
\hline Roof / Streha & 8 & 6.3 & 122 & 122 & 26.9 \\
\hline Other (building) / Drugo (stavba) & 7 & 5.5 & $2 \mathrm{I}$ & $2 \mathrm{I}$ & 4.6 \\
\hline Tree hole / Duplo & 21 & 16.5 & 65 & 66 & 14.5 \\
\hline $\begin{array}{l}\text { Area of damaged branch / Poškodovana veja } \\
\text { na drevesu }\end{array}$ & 3 & 2.4 & 5 & 5 & I.I \\
\hline Nest box / Gnezdilnica & I & 0.8 & $\circ$ & I & $0 . \mathrm{I}$ \\
\hline
\end{tabular}

Table 6: Tree species used for nesting by Jackdaws Corvus monedula ( $\mathrm{N}=76-78$ pairs)

Tabela 6: Vrste gnezdilnih dreves kavk Corvus monedula ( $\mathrm{N}=76-78$ parov)

\begin{tabular}{|c|c|c|c|c|c|}
\hline \multirow[b]{2}{*}{ Tree species / Vrsta drevesa } & \multirow{2}{*}{$\begin{array}{l}\text { No. of } \\
\text { colonies or } \\
\text { locations/ } \\
\text { Št. kolonij } \\
\text { oz. lokacij }\end{array}$} & \multirow{2}{*}{$\begin{array}{l}\text { Percentage } \\
\text { of locations/ } \\
\text { Odstotek } \\
\text { lokacij }(\%)\end{array}$} & \multicolumn{2}{|c|}{ No. of pairs / Št. parov } & \multirow{2}{*}{$\begin{array}{l}\text { Percentage } \\
\text { of pairs/ } \\
\text { Odstotek } \\
\text { parov (\%) }\end{array}$} \\
\hline & & & $\min$ & $\max$ & \\
\hline Fagus sylvatica & I 4 & 51.9 & 42 & 43 & 53.1 \\
\hline Platanus sp. & 6 & 22.2 & 24 & 25 & 30.6 \\
\hline Fraxinus excelsior / oxycarpa & 2 & $7 \cdot 4$ & 8 & 8 & 10.0 \\
\hline Aesculus hippocastanum* & $2(\mathrm{~B})$ & 7.4 & I & 2 & 1.9 \\
\hline Quercus robur* & $\mathrm{I}(\mathrm{T})$ & $3 \cdot 7$ & 2 & 2 & 2.5 \\
\hline Unknown tree / Neznano drevo* & $\mathrm{I}(\mathrm{B})$ & $3 \cdot 7$ & I & I & 1.3 \\
\hline Nest box on tree / Gnezdilnica na drevesu* & I (B) & 3.7 & ० & I & 0.6 \\
\hline
\end{tabular}

Pairs using these tree species were part of larger colonies, nesting predominantly on buildings (B) or other trees (T). / Pari, ki so uporabljali te drevesne vrste, so pripadali večjim kolonijam, pretežno gnezdečim na stavbah $(\mathrm{B})$ ali drugih drevesih $(\mathrm{T})$. 
under $400 \mathrm{~m}$ a.s.l. (Figure 12). Only five occupied sites (48-49 pairs, $6.7 \%$ of the total) are located higher than $500 \mathrm{~m}$ a.s.l. Begunje na Gorenjskem (578 m a.sl.) held the colony breeding at the highest altitude in Slovenia.

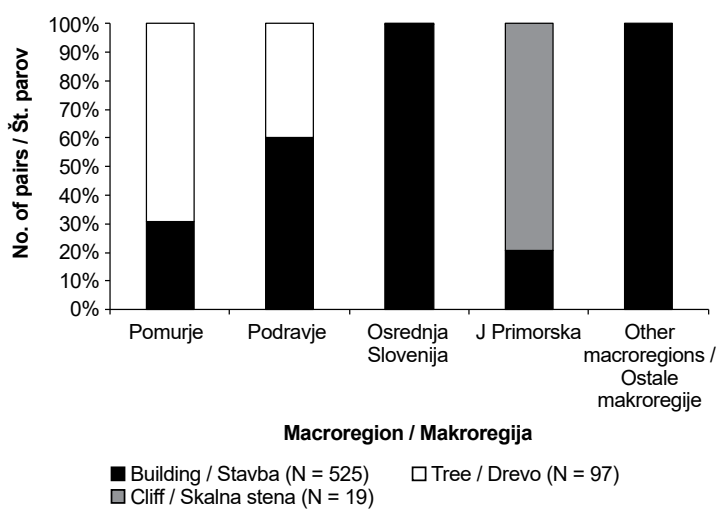

Figure 5: Percentage of Jackdaw Corvus monedula pairs ( $N=641$ pairs, max. no. of pairs) at different nest site types in macroregions of Slovenia in 2008-2011

Slika 5: Odstotek parov kavke Corvus monedula ( $N=641$ parov, max. št. parov) na različnih tipih gnezdišč v makroregijah Slovenije v letih 2008-2011

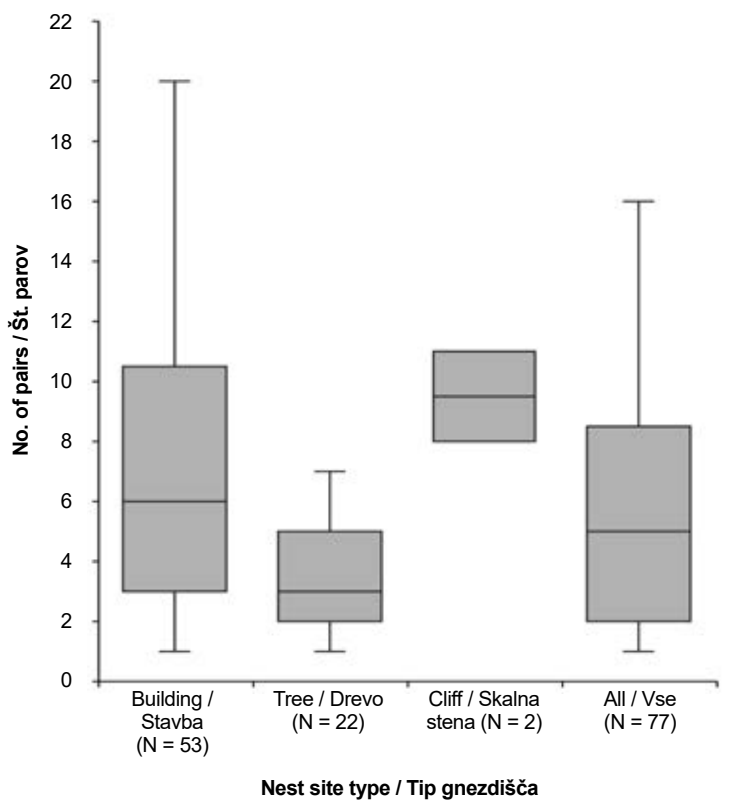

Figure 6: Colony size of Jackdaws Corvus monedula $(\mathrm{N}=$ 77) at different nest site types in Slovenia in 2008-2011

Slika 6: Velikost kolonije kavk Corvus monedula $(\mathrm{N}=77)$ na različnih tipih gnezdišč v Sloveniji v letih 2008-2011

\subsection{Past numbers and distribution}

The Ornithological Atlas of Slovenia (records from 1979-1994) recorded breeding Jackdaws in 74 UTM $10 \mathrm{~km}$ squares; during this study, they were registered in 51 squares. Main differences include an almost complete absence of the species from the Karst Plateau (SW Slovenia) and narrower valleys in the alpine part of the country in 2008-2011. Moreover, distribution of the species was formerly more extensive and continuous in Central and NE Slovenia (Figure 4).

Jackdaw occurred at a minimum of 48 specific sites (in most cases colonies with known locations) in the past, but became extinct there by the time of this study. In further nine colonies, the number of breeding pairs decreased by $>20 \%$. Taking into consideration possible nest site shifts between neighbouring sites, ignoring past colonies of unknown size, at least 217-254 pairs were lost at these sites (Table 7, Figure 2).

\section{Discussion}

The first ever successful country-wide census of breeding Jackdaws revealed a national population of several hundred pairs, substantially fewer than estimated previously (GEISTER I995, BIRDLIFE INTERNATIONAL 2004).

Despite good coverage partly achieved by extending the census over four years, it seems likely that some pairs were missed. This probably holds true for the unsurveyed parts of Ljubljana (e.g. one such part of the Šiška district held 22 pairs in 2000, P. TRONTELJ in litt.) and forest nesting population in NE Slovenia where the habitat is difficult to survey and Jackdaws are wary and inconspicuous (Cramp \& Perrins i 994, Hoi-Leitner et al. 2016). Moreover, small numbers may have remained unnoticed elsewhere in the country. Overestimating the number of pairs due to the inclusion of non-breeders present at nest sites (cf. DVORAK 1996, HENDERSON $e t$ al. 2000) was probably offset by the overlooked pairs, especially in large colonies, densely populated areas and nest sites high above the ground (e.g. tower blocks). Considering these limitations, the total Slovene Jackdaw breeding population in the late 2000 s was probably in the range of 700-900 pairs. Thus, taking into consideration the surface area, our population size is comparable with those given for similar countries in Central Europe (BirdLife InTERNATIONAL 2015).

The breeding distribution was patchy with fairly continuous occurrence at the $10 \mathrm{~km}$ UTM level only in a few widely separated areas, covering less than a quarter of Slovenia. Due to the fairly specific habitat requirements of the species, such a pattern 
Table 7: Jackdaw Corvus monedula colonies and sites known prior to 2008 in Slovenia but not recorded in this study, and colonies with severely reduced no. of pairs ( $\mathrm{N}=57$ ). For comparison, please refer to Table 1. Macroregions according to PLUT (1999).

Tabela 7: Kolonije in kraji gnezdenja kavk Corvus monedula v Sloveniji, znani pred letom 2008, ki v tej raziskavi niso bili zabeleženi, ter kolonije, v katerih se je št. parov občutno zmanjšalo ( $N=57)$ (primerjaj s tabelo 1). Makroregije po PLutu (1999).

\begin{tabular}{|c|c|c|c|c|c|c|c|c|c|}
\hline \multirow{2}{*}{$\begin{array}{l}\text { Macroregion/ } \\
\text { Makroregija }\end{array}$} & \multirow{2}{*}{$\begin{array}{l}\text { Settlement/ } \\
\text { Naselje }\end{array}$} & \multirow{2}{*}{$\begin{array}{l}\text { Nest site type, } \\
\text { subtype/ } \\
\text { Tip, podtip } \\
\text { gnezdišča }\end{array}$} & \multirow{2}{*}{$\begin{array}{l}\text { Year/ } \\
\text { Leto }\end{array}$} & \multirow{2}{*}{$\begin{array}{l}\text { Type of } \\
\text { observation/ } \\
\text { Vrsta } \\
\text { opazovanja }\end{array}$} & \multicolumn{2}{|c|}{$\begin{array}{l}\text { No. of pairs/ } \\
\text { Št. parov }\end{array}$} & \multirow[b]{2}{*}{ Status } & \multirow{2}{*}{$\begin{array}{l}\text { Cause/ } \\
\text { Vzrok }\end{array}$} & \multirow[b]{2}{*}{ Source / Vir } \\
\hline & & & & & $\min$ & $\max$ & & & \\
\hline Pomurje & Adrijanci & $2 b$ & 1998 & GN & 5 & 7 & Ex & & $\begin{array}{l}\text { ŠTUMBERGER } \\
(2003)\end{array}$ \\
\hline Pomurje & Dolenci & $2 b$ & 1998 & GN & 5 & 5 & Ex & & $\begin{array}{l}\text { ŠTUMBERGER } \\
(2003)\end{array}$ \\
\hline Pomurje & Pertoča & I & 2000 & GN & 2 & 2 & Ex & $\mathrm{D}$ & $\begin{array}{l}\text { S. FORJANIČ, } \\
\text { T. BÖRC }\end{array}$ \\
\hline Pomurje & Ljutomer & $\mathrm{I}, 2$ & $\begin{array}{l}80 \mathrm{~s} / \\
80-\mathrm{ta}\end{array}$ & GN & $?$ & $?$ & Ex & & Ž.ŠALAMUN \\
\hline Pomurje & Radenci & I & $\begin{array}{l}80 \mathrm{~s} / \\
80-\mathrm{ta}\end{array}$ & GN & $?$ & $?$ & Ex & & Ž.ŠALAMUN \\
\hline Pomurje & Veržej & nez. & 1986 & GN & $?$ & $?$ & Ex & & $\begin{array}{l}\text { BIBIČ \& } \\
\text { JANŽEKOVIČ } \\
(I 986)\end{array}$ \\
\hline Podravje & $\begin{array}{l}\text { Sv. Ana v } \\
\text { Slovenskih } \\
\text { goricah }\end{array}$ & Id & 2002 & GN & I 8 & I8 & Ex & $\mathrm{R}$ & NOAGS \\
\hline Podravje & Sp. Hoče & Id & 1994 & GN & 9 & 9 & Ex & $\mathrm{R}$ & F. BRAČKO \\
\hline Podravje & $\begin{array}{l}\text { Hrastovec v } \\
\text { Slovenskih } \\
\text { goricah }\end{array}$ & Ie & 1984 & GN & 8 & 8 & Ex & & F. BRAČKO \\
\hline Podravje & $\begin{array}{l}\text { Slivnica pri } \\
\text { Mariboru }\end{array}$ & Id & 1993 & GN & 8 & 8 & Ex & $\mathrm{R}$ & $\begin{array}{l}\text { VOGRIN } \\
\text { (1998) }\end{array}$ \\
\hline Podravje & Sp. Dobrenje & If & 1992 & GN & 6 & 6 & Ex & & F. BRAČKO \\
\hline Podravje & Maribor & $\mathrm{Ih}^{1}$ & 1980 & GN & 4 & 6 & Ex & & F. BRAČKO \\
\hline Podravje & Sp. Polskava & Id & 1993 & GN & 4 & 4 & Ex & & F. BRAČKO \\
\hline Podravje & Kušernik & $2 \mathrm{~d}$ & 1985 & GN & 3 & 3 & Ex & & F. BRAČKO \\
\hline Podravje & $\begin{array}{l}\text { Pesnica pri } \\
\text { Mariboru }\end{array}$ & I & 1982 & GN & 3 & 3 & Ex & & F. BRAČKO \\
\hline Podravje & Rače & $2 \mathrm{~d}$ & I988 & GN & 2 & 2 & Ex & & VOGRIN (1998) \\
\hline Podravje & $\begin{array}{l}\text { Sp. Jakobski } \\
\text { Dol }\end{array}$ & Ia & 1995 & GN & 2 & 2 & Ex & & F. BRAČKO \\
\hline Podravje & Hajdoše & Ia & 1992 & GN & I & I & Ex & & BRAČKO (1997) \\
\hline Podravje & Hotinja vas & $2 \mathrm{~d}$ & 1987 & GN & I & I & Ex & & VOGRIN (1998) \\
\hline Podravje & Loka & Ia & 1992 & GN & I & I & Ex & & BRAČKO (1997) \\
\hline Podravje & $\begin{array}{l}\text { Miklavž na } \\
\text { Dravskem } \\
\text { polju }\end{array}$ & Ia & 1992 & GN & $\mathrm{I}$ & I & Ex & & $\begin{array}{l}\text { BRAČKO } \\
\text { (1997) }\end{array}$ \\
\hline Podravje & Pekre & ia & 1992 & GN & $\mathrm{I}$ & I & Ex & & F. BRAČKO \\
\hline Podravje & Rače & ia & 1993 & GN & I & I & Ex & & F. BRAČKO \\
\hline Podravje & Maribor & Ig & 1999 & GN & o & I & Ex & & F. BRAČKO \\
\hline Podravje & Pragersko & I & 1993 & GN & 30 & 30 & $\downarrow$ & & F. BRAČKO \\
\hline
\end{tabular}




\begin{tabular}{|c|c|c|c|c|c|c|c|c|c|}
\hline \multirow{2}{*}{$\begin{array}{l}\text { Macroregion/ } \\
\text { Makroregija }\end{array}$} & \multirow{2}{*}{$\begin{array}{l}\text { Settlement/ } \\
\text { Naselje }\end{array}$} & \multirow{2}{*}{$\begin{array}{l}\text { Nest site type, } \\
\text { subtype/ } \\
\text { Tip, podtip } \\
\text { gnezdišča }\end{array}$} & \multirow{2}{*}{$\begin{array}{l}\text { Year/ } \\
\text { Leto }\end{array}$} & \multirow{2}{*}{$\begin{array}{l}\text { Type of } \\
\text { observation/ } \\
\text { Vrsta } \\
\text { opazovanja }\end{array}$} & \multicolumn{2}{|c|}{$\begin{array}{l}\text { No. of pairs/ } \\
\text { Št. parov }\end{array}$} & \multirow[b]{2}{*}{ Status } & \multirow{2}{*}{$\begin{array}{l}\text { Cause/ } \\
\text { Vzrok }\end{array}$} & \multirow[b]{2}{*}{ Source / Vir } \\
\hline & & & & & $\min$ & $\max$ & & & \\
\hline Podravje & Ptuj & I & 1992 & GN & 30 & 30 & $\downarrow$ & $\mathrm{R}$ & $\begin{array}{l}\text { BRAČKO } \\
(1997)\end{array}$ \\
\hline Podravje & Podova* & Ia & 2004 & GN & 23 & 23 & $\downarrow$ & $\mathrm{R}$ & NOAGS \\
\hline Podravje & Sveta Trojica & Id & 2004 & GN & I 4 & I 4 & $\downarrow$ & & NOAGS \\
\hline $\begin{array}{l}\text { Savinjska } \\
\text { Slovenija }\end{array}$ & Sedlarjevo & - & 1999 & PREH & $\circ$ & I & Ex & & $\begin{array}{l}\text { JANČAR \& } \\
\text { TREBUŠAK } \\
\text { (2000), KMECL } \\
\text { et al. (2014) }\end{array}$ \\
\hline JV Slovenija & Dobova & nez. & 2001 & PREL & ० & IO & Ex & & L. BožıČ \\
\hline JV Slovenija & $\begin{array}{l}\text { Krakovski } \\
\text { gozd }\end{array}$ & $2 \mathrm{a}$ & 1976 & GN & $?$ & $?$ & Ex & & $\begin{array}{l}\text { GREGORI } \\
(1992)\end{array}$ \\
\hline JV Slovenija & Krško & nez. & 2006 & GN & 4 & 4 & $\downarrow$ & & NOAGS \\
\hline $\begin{array}{l}\text { Osrednja } \\
\text { Slovenija }\end{array}$ & $\begin{array}{l}\text { Ljubljana- } \\
\text { Šentvid }\end{array}$ & Ia, Ib & 2000 & GN & 19 & 19 & Ex & & P. Trontelj \\
\hline $\begin{array}{l}\text { Osrednja } \\
\text { Slovenija }\end{array}$ & $\mathrm{Ig}$ & Id & 2002 & GN & 12 & 13 & Ex & $\mathrm{R}$ & $\begin{array}{l}\text { TOME et al. } \\
(2005)\end{array}$ \\
\hline $\begin{array}{l}\text { Osrednja } \\
\text { Slovenija }\end{array}$ & Rakitnik & - & 1986 & PREH & 7 & 8 & Ex & & S. PolaK \\
\hline $\begin{array}{l}\text { Osrednja } \\
\text { Slovenija }\end{array}$ & $\begin{array}{l}\text { Ljubljana } \\
\text { (Verovškova } \\
51 \text { ) }\end{array}$ & $\mathrm{Ib}$ & 1999 & $\mathrm{GN}$ & 4 & 4 & $\mathrm{Ex}$ & & P. TRontelJ \\
\hline $\begin{array}{l}\text { Osrednja } \\
\text { Slovenija }\end{array}$ & $\begin{array}{l}\text { Nova vas, } \\
\text { Bloke }\end{array}$ & nez. & 2006 & GN & 2 & 2 & Ex & & NOAGS \\
\hline $\begin{array}{l}\text { Osrednja } \\
\text { Slovenija }\end{array}$ & $\begin{array}{l}\check{S}_{\text {martno pri }} \\
\text { Litiji }\end{array}$ & nez. & 2007 & GN & I & I & Ex & & NOAGS \\
\hline $\begin{array}{l}\text { Osrednja } \\
\text { Slovenija }\end{array}$ & $\begin{array}{l}\text { Dobravica } \\
\text { pri Igu }\end{array}$ & Id & 1981 & GN & $?$ & $?$ & Ex & & Sovinc (1990) \\
\hline $\begin{array}{l}\text { Osrednja } \\
\text { Slovenija }\end{array}$ & Trboje* & $3 a$ & 1985 & GN & $?$ & ? & Ex & $\mathrm{F}$ & $\begin{array}{l}\text { GEISTER } \\
(\text { I995) }\end{array}$ \\
\hline $\begin{array}{l}\text { Osrednja } \\
\text { Slovenija }\end{array}$ & Zbilje* & $3 a$ & $\begin{array}{l}70 s / \\
70-t a\end{array}$ & GN & $?$ & $?$ & Ex & $\mathrm{H}, \mathrm{D}$ & M.ŽNIDARŠIČ \\
\hline $\begin{array}{l}\text { Osrednja } \\
\text { Slovenija }\end{array}$ & $\begin{array}{l}\text { Ljubljana- } \\
\text { Dravlje }^{+}\end{array}$ & Ig & 2000 & GN & 18 & I 8 & $\downarrow$ & & P. TRONTELJ \\
\hline $\begin{array}{l}\text { Osrednja } \\
\text { Slovenija }\end{array}$ & $\begin{array}{l}\text { Ljubljana } \\
(\text { Celovška } \\
26 \text { in } 28)^{*++}\end{array}$ & $\mathrm{Ib}$ & $\begin{array}{l}90 s / \\
90-t a\end{array}$ & GN & IO & 15 & $\downarrow$ & & P. TRONTELJ \\
\hline Gorenjska & Belca & nez. & 2006 & GN & 2 & 2 & Ex & & NOAGS \\
\hline Gorenjska & Lesce & nez. & 2006 & GN & 2 & 2 & Ex & & NOAGS \\
\hline Gorenjska & Dovje & I & 2006 & GN & I & I & Ex & & NOAGS \\
\hline Gorenjska & $\begin{array}{l}\text { Begunje na } \\
\text { Gorenjskem }\end{array}$ & Id & 2006 & GN & 4 & 4 & $\downarrow$ & & NOAGS \\
\hline Gorenjska & Breznica & Id & 2006 & GN & 4 & 4 & $\downarrow$ & & NOAGS \\
\hline
\end{tabular}




\begin{tabular}{|c|c|c|c|c|c|c|c|c|c|}
\hline \multirow{2}{*}{$\begin{array}{l}\text { Macroregion/ } \\
\text { Makroregija }\end{array}$} & \multirow{2}{*}{$\begin{array}{l}\text { Settlement/ } \\
\text { Naselje }\end{array}$} & \multirow{2}{*}{$\begin{array}{l}\text { Nest site type, } \\
\text { subtype/ } \\
\text { Tip, podtip } \\
\text { gnezdišča }\end{array}$} & \multirow{2}{*}{$\begin{array}{l}\text { Year/ } \\
\text { Leto }\end{array}$} & \multirow{2}{*}{$\begin{array}{l}\text { Type of } \\
\text { observation/ } \\
\text { Vrsta } \\
\text { opazovanja }\end{array}$} & \multicolumn{2}{|c|}{$\begin{array}{l}\text { No. of pairs/ } \\
\text { Št. parov }\end{array}$} & \multirow[b]{2}{*}{ Status } & \multirow{2}{*}{$\begin{array}{l}\text { Cause/ } \\
\text { Vzrok }\end{array}$} & \multirow[b]{2}{*}{ Source / Vir } \\
\hline & & & & & $\min$ & $\max$ & & & \\
\hline S Primorska & Tolmin & - & 2005 & PREH & I & 2 & Ex & & NOAGS \\
\hline S Primorska & Miren & Id & 1993 & GN & $?$ & $?$ & Ex & & B. KUMAR \\
\hline J Primorska & $\begin{array}{l}\text { Podtabor, } \\
\text { Ilirska } \\
\text { Bistrica }\end{array}$ & $3 a$ & 1984 & GN & 6 & 7 & Ex & & S. PolaK \\
\hline J Primorska & Piran* & $\mathrm{Ih}^{2}$ & $\begin{array}{l}90 \mathrm{~s} / \\
90-\mathrm{ta}\end{array}$ & GN & IO & 20 & Ex & $\mathrm{R}$ & $\begin{array}{l}\check{S}_{\text {KORNIK }} \\
(20 \text { I 2), I. } \\
\text { ŠKORNIK }\end{array}$ \\
\hline J Primorska & $\begin{array}{l}\text { Sečoveljske } \\
\text { soline }\end{array}$ & $\mathrm{Ih}^{3}$ & $\begin{array}{l}80 s / \\
80-\text { ta }\end{array}$ & GN & 3 & 3 & Ex & & $\begin{array}{l}\check{S}_{\text {KORNIK }} \\
(20 \text { I 2), I. } \\
\text { ŠKORNIK }\end{array}$ \\
\hline J Primorska & Osp & $3 a$ & $\begin{array}{l}90 \mathrm{~s} / \\
90-\mathrm{ta}\end{array}$ & GN & $?$ & $?$ & Ex & & $\begin{array}{l}\text { MARČETA } \\
(1994)\end{array}$ \\
\hline J Primorska & Podpeč & $3 a$ & $\begin{array}{l}90 s / \\
90-\mathrm{ta}\end{array}$ & GN & $?$ & $?$ & Ex & & $\begin{array}{l}\text { MARČETA } \\
(1994)\end{array}$ \\
\hline J Primorska & Podpeč & $3 a$ & $\begin{array}{l}90 s / \\
90-\mathrm{ta}\end{array}$ & GN & $?$ & $?$ & Ex & & $\begin{array}{l}\text { MARČETA } \\
(\text { I } 994)\end{array}$ \\
\hline J Primorska & Sočerga & $3 a$ & $\begin{array}{l}90 s / \\
90-\text { ta }\end{array}$ & GN & $?$ & $?$ & Ex & & $\begin{array}{l}\text { MARČETA } \\
(1994)\end{array}$ \\
\hline
\end{tabular}

\section{Legend / Legenda}

Settlement: for non-urban records, the name of the nearest settlement is given; Year: accurate year or decade to which information refers; Nest site type and subtype: 1 - building, 2 - tree, $1 \mathrm{a}$ - one- and two-storey residential building, $1 \mathrm{~b}$ multi-storey residential building, $1 \mathrm{c}$ - tower block, $1 \mathrm{~d}$ - church, 1e - castle, 1f - outbuilding, $1 \mathrm{~g}$ - industrial building, $1 \mathrm{~h}$ other building, $2 \mathrm{a}$ - continuous forest, $2 \mathrm{~b}$ - isolated wood in open agricultural landscape, $2 \mathrm{~d}$ - orchard, $3 \mathrm{a}$ - natural cliff; Type of observation: GN - breeding, PREH - foraging, PREL - flying over; Number of pairs: ? - unknown; Status: EX extinct, $\downarrow$ - decline by > 20\%; Cause of extinction/decline (if known): D - pulling down of the building, R - renovation of the building, $\mathrm{F}$ - flooding of the area by river damming, $\mathrm{H}$ - harvesting, D - disturbance at nest site

Naselje: pri neurbanih podatkih je navedeno ime najbližjega naselja; Leto: leto oziroma desetletje, na katero se nanaša podatek; Tip in podtip gnezdišča: 1 - stavba, 2 - drevo, la - eno- in dvo-nadstropna stanovanjska hiša, 1 b - večnadstropna stanovanjska hiša, 1c - stolpnica, 1d - cerkev, le - grad, lf - gospodarsko poslopje, 1g - industrijski objekt, 1h - druga stavba, 2a - sklenjen gozd, 2b - izoliran gozdiček v odprti kmetijski krajini, 2d - sadovnjak, 3a - naravna skalna stena; Vrsta opazovanja: GN - gnezdenje, PREH - prehranjevanje, PREL - prelet; Število parov: ? - neznano; Status: EX - izumrla, $\downarrow$ - upad za > $20 \%$; Vzrok izumrtja/upada, če je znan: D - porušenje stavbe, $R$ - obnova stavbe, $F$ - potopitev območja $z$ zajezitvijo reke, $\mathrm{H}$ - lov oz. pobiranje osebkov, D - motnje na gnezdišču

Pairs from the colony probably moved to other site(s) in vicinity, occupied during this study / Pari iz kolonije so se verjetno prestavili v drug(e) kraj(e) v bližini, zasedene v času te raziskave

$+\quad 10-12$ pairs in $2008 / 10-12$ parov leta 2008

++ 7-8 pairs in 2008 ( 2 at Celovška 26 and 5-6 at neighbouring factory complex) / 7-8 parov leta 2008 ( 2 na Celovški 26 in $5-6$ na sosednji tovarni)

Barracks / Vojašnica

Outer wall of the church / Obzidje cerkve

3 Abandoned traditional saltworkers' houses / Opuščene solinarske hiše 


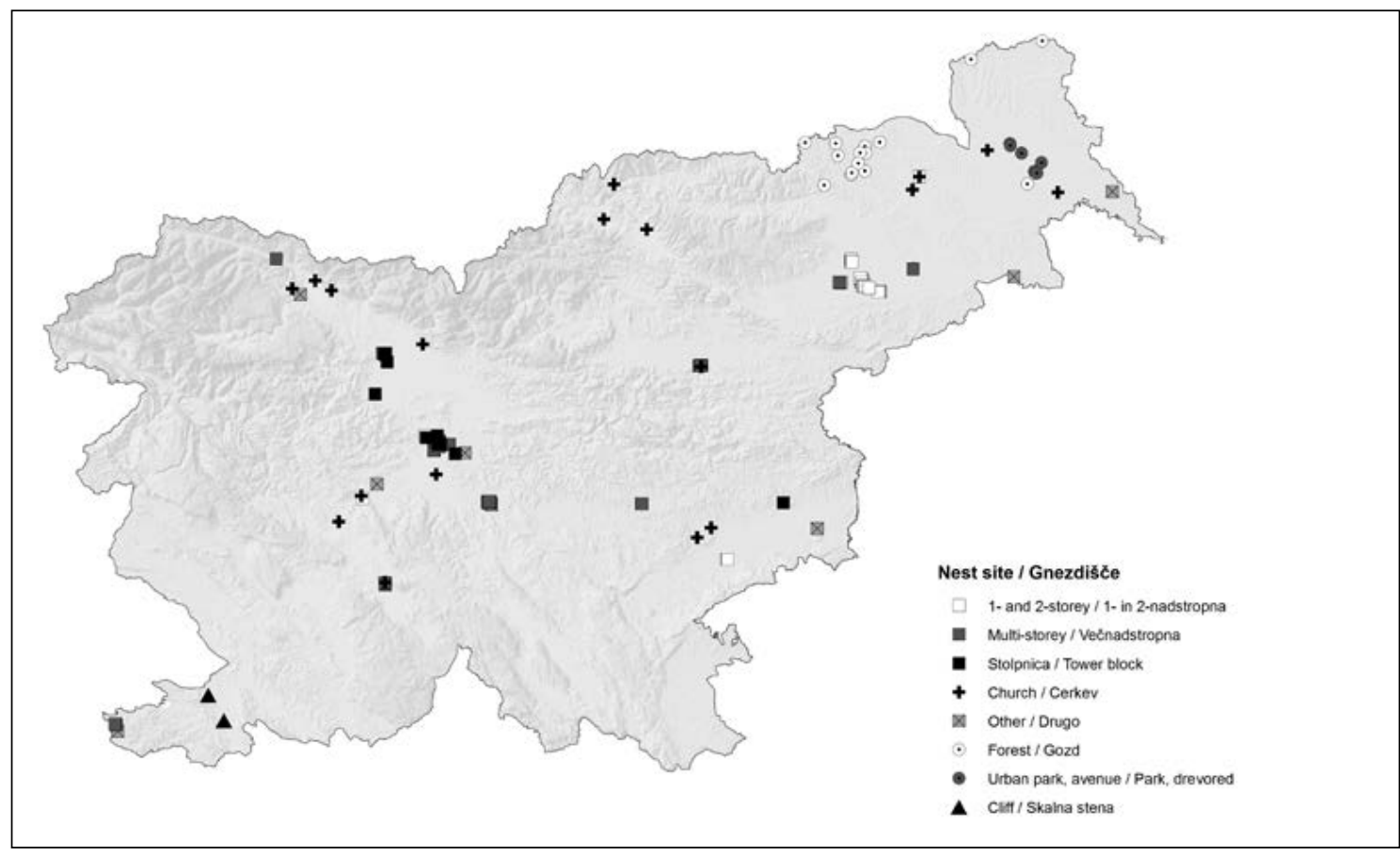

Figure 7: Distribution of nest site subtypes of Jackdaws Corvus monedula in Slovenia in 2008-2011 ( $N=170)$

Slika 7: Razširjenost podtipov gnezdišč kavke Corvus monedula v Sloveniji v letih 2008-2011 (N=170)

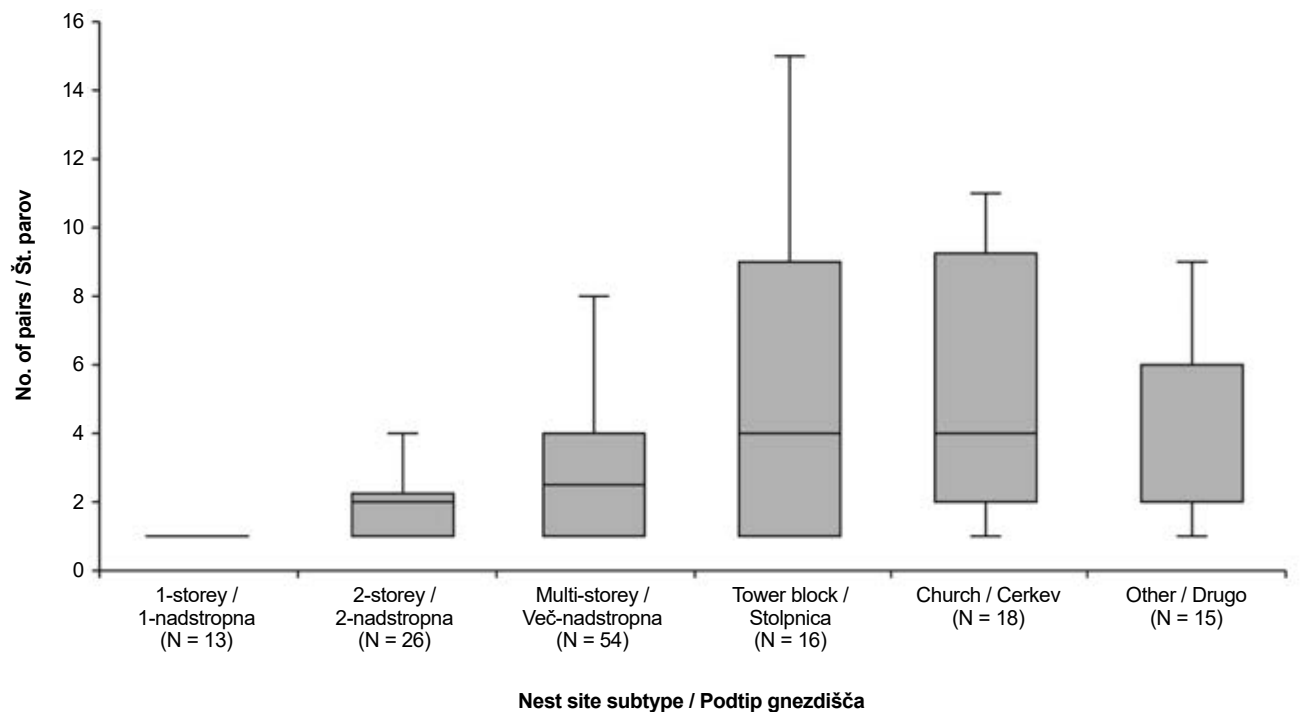

Figure 8: Number of Jackdaw Corvus monedula pairs nesting on individual building of a given subtype in Slovenia in 2008-2011 ( $N=142)$

Slika 8: Število parov kavke Corvus monedula, gnezdečih na posamezni stavbi določenega podtipa v Sloveniji v letih 2008-2011 ( $=142)$ 
(A)

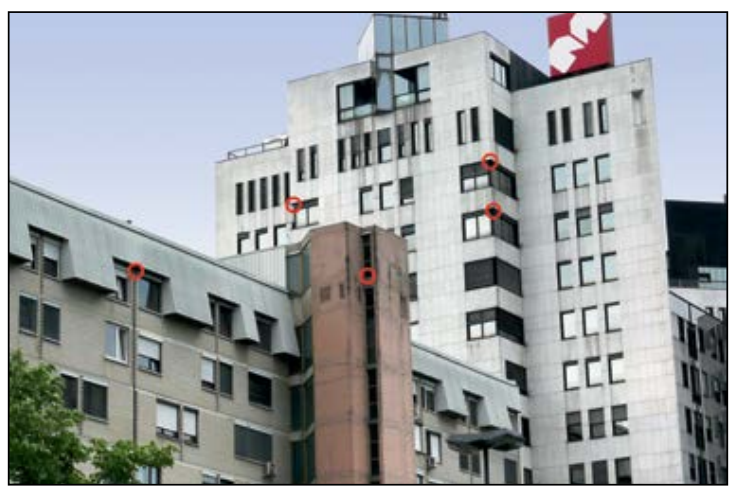

(C)

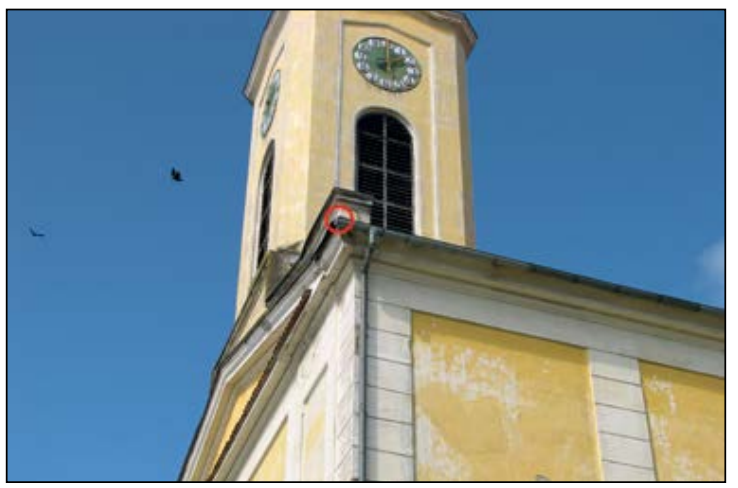

(E)

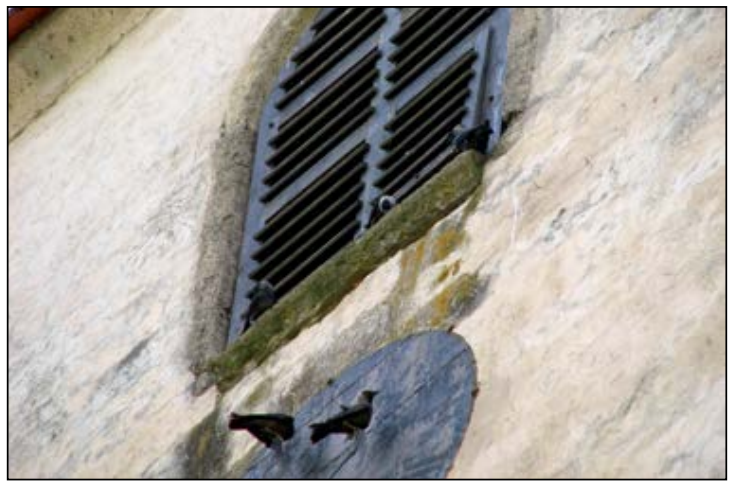

(B)

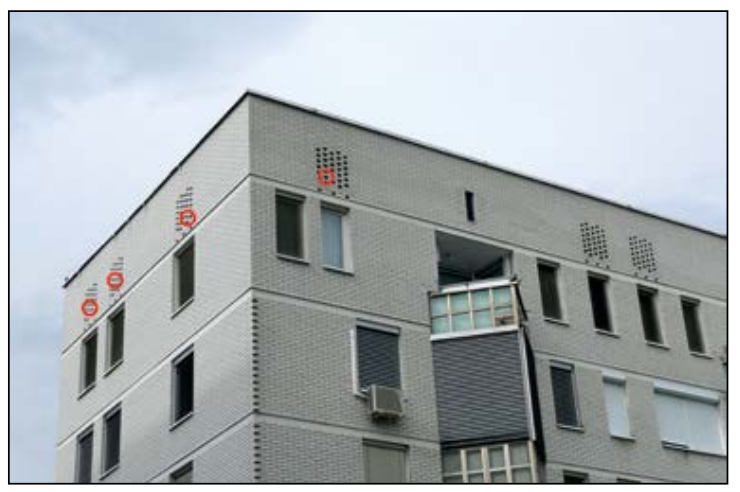

(D)

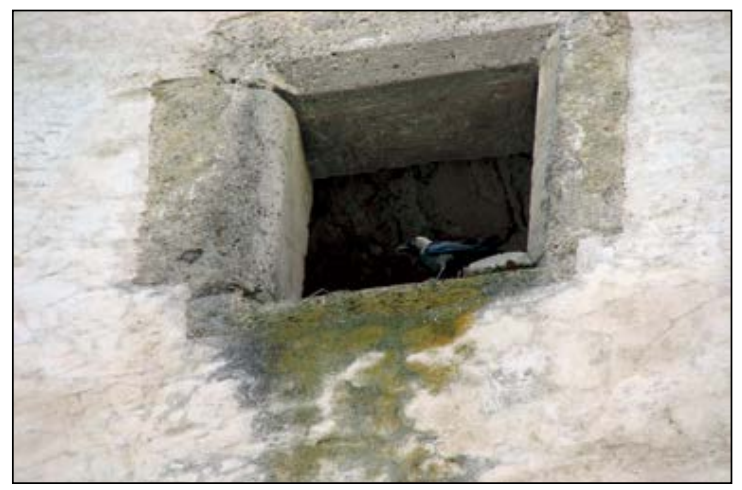

(F)

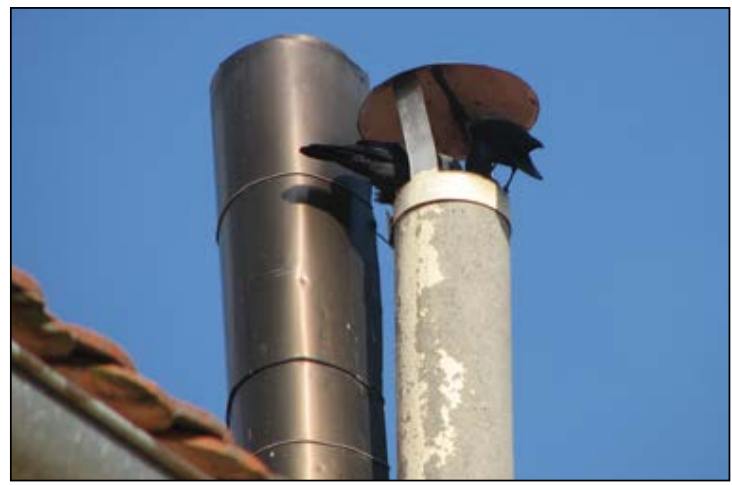

Figure 9: Examples of Jackdaw Corvus monedula nest site subtypes and nest hole placements on buildings in Slovenia in 20082011: (A) tower block on Dunajska street and (B) multi-storey residential building on Mašera-Spasićeva street, Ljubljana - both locations are part of the largest colony in Slovenia (circles delineate nest holes in window corners and walls, respectively) (photo: D. Fekonja); (C) Church of St. Cross, Crenšovci (nest holes in outer edge of the roof behind rain gutter); Church of the Epiphany, Sv. Trije kralji v Slovenskih goricah - (D) entrance to the nest in a bell tower through wall opening and (E) through window shutter in a belfry (photo: L. Božič); (F) chimney pot of a one-storey residential house, Cirkovce (Dravsko polje) (photo: M. Kerček)

Slika 9: Primeri podtipov gnezdišč kavke Corvus monedula in mest gnezdilnih lukenj na stavbah v Sloveniji v letih 2008-2011: (A) stolpnica na Dunajski cesti in (B) večnadstropna stanovanjska hiša na Mašera-Spasićevi ulici v Ljubljani - obe lokaciji sta del največje kolonije v Sloveniji (krogi označujejo gnezdilne luknje v vogalih oken in stenah) (foto: D. Fekonja); (C) cerkev sv. Križa v Črenšovcih (gnezdilne luknje v zunanjem robu strehe za žlebom); cerkev sv. Treh kraljev v Slovenskih goricah - (D) vhod do gnezda v zvoniku skozi odprtino v zidu in (E) skozi okno s polkni (foto: L. Božič); (F) dimnik na enonadstropni stanovanjski hiši v Cirkovcah (Dravsko polje) (foto: M. Kerček) 
(A)

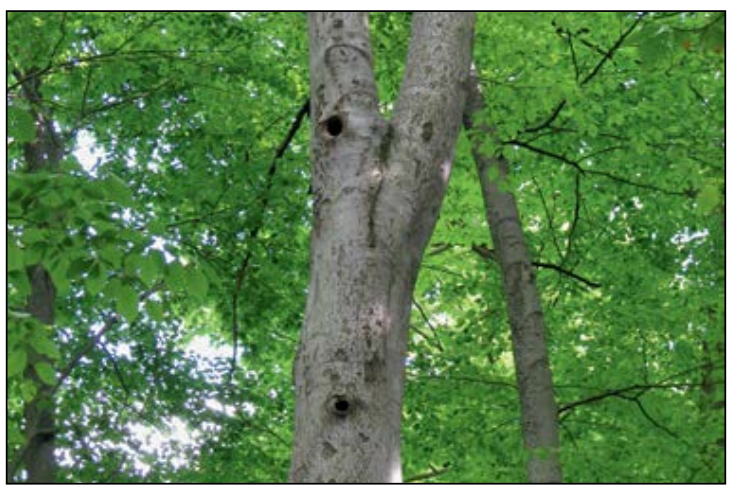

(C)

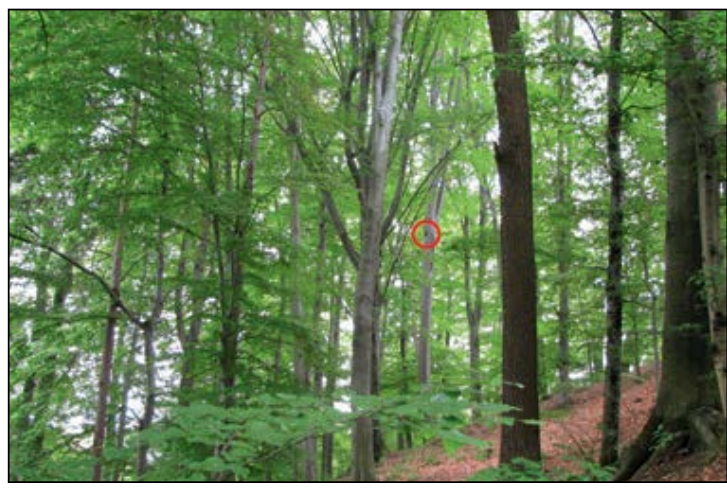

(E)

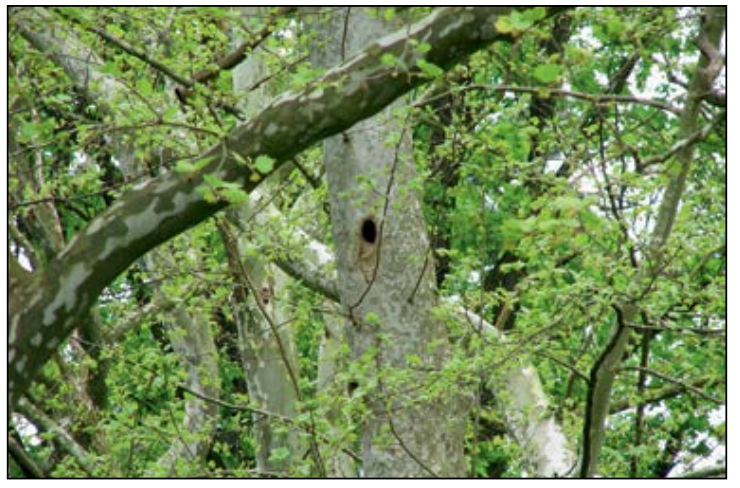

(B)

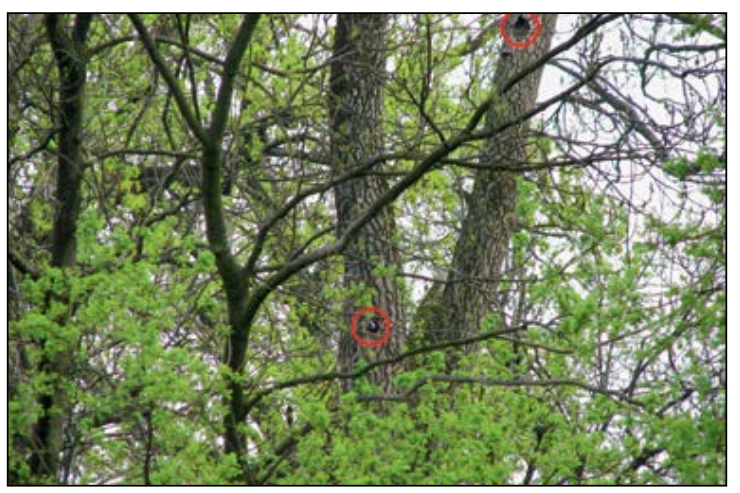

(D)

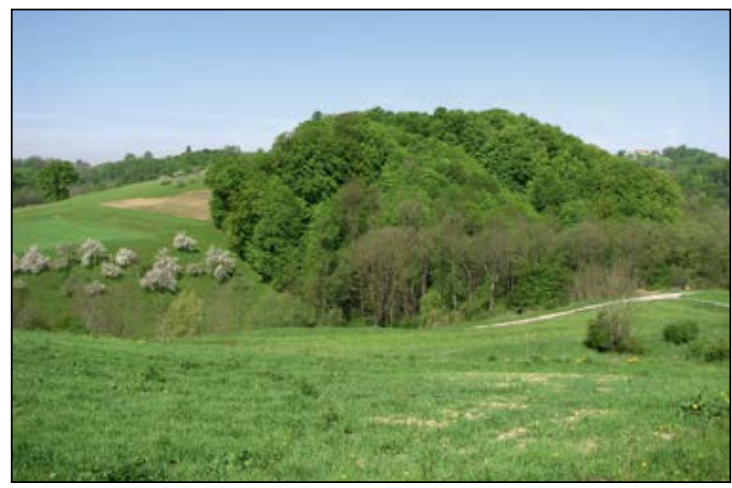

$(\mathrm{F})$

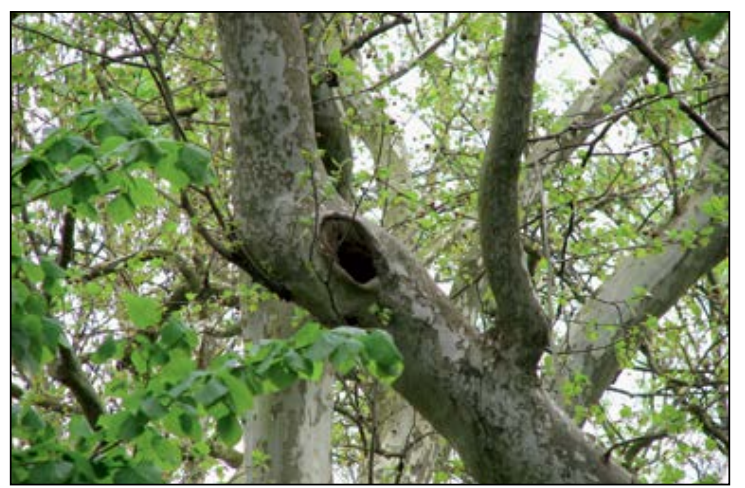

Figure 10: Nest hole placements of tree-nesting Jackdaws Corvus monedula in Slovenia in 2008-2011: (A) tree hole in a beech, excavated by Black Woodpecker Dryocopus martius (upper hole used by Jackdaw), Počenik (Slovenske gorice); (B) multiple occupied holes in a single ash tree with nesting material protruding from the upper hole, Beltinci; (C) interior of the beech wood with a nesting tree, Rošpoh (Slovenske gorice); (D) small wood situated in open agricultural landscape - typical Jackdaw nest site in the latter area; $(E)$ tree hole and $(F)$ cavity formed on the spot where branch was broken in planes in urban park, Murska Sobota (photo: L. Božič)

Slika 10: Mesta gnezdilnih lukenj kavk Corvus monedula na drevesih v Sloveniji v letih 2008-2011: (A) duplo črne žolne Dryocopus martius v bukvi (zgornjo je uporabljala kavka) pri Počeniku (Slovenske gorice); (B) več zasedenih dupel v enem jesenu, kjer iz zgornjega štrli gnezditveni material, Beltinci; (C) notranjost bukovega gozda z gnezdilnim drevesom, Rošpoh (Slovenske gorice); (D) izoliran gozdiček sredi kulturne krajine - tipično gnezdišče kavke na slednjem območju; (E) duplo in (F) votlina, nastala na točki, kjer je bila odlomljena veja, na platanah v mestnem parku v Murski Soboti (foto: L. Božič) 
is characteristic for large parts of its range, notably in Central Europe (DvoraK et al. 1993, Cramp \& Perrins i994, Bauer et al. 2005, Maumary et al. 2007, GEDEON et al. 2014). Given the large forest area (ZGS 20II) and high proportion of elevations over $500 \mathrm{~m}$ a.s.l. (Š́EHĆ et al. 2010), similar situation in Slovenia is rather expected.

Breeding densities were high in some of the largest urban centres in the country (e.g. Kranj, Ljubljana). These were broadly similar to urban densities in different parts of Europe (e.g. Brussels, Leverkusen, Vienna, Rome, Naples), but were also up to severalfold smaller than urban densities reported for some Dutch (Amsterdam, Alkmaar, Delft) and Polish cities (Warsaw, Olsztyn, Zielona Góra) (Dwenger 1995, SAlVATi 2002B, CZechowski et al. 2013 , Hoi-Leitner et al. 2016). However, urban densities can be inflated as foraging grounds may actually lie outside built-up zones included in the surface area used for density calculation (SALVATI 2002B), as is probably the case of Kranj in this study. Densities over extensive regions $\left(>200 \mathrm{~km}^{2}\right)$ are more representative, because they are largely unaffected by plot size (SALVATI 2002B). Densities in two regions of central Slovenia (Savska ravan, Dolenjsko podolje) were higher than in all districts of Austrian Styria and former East Germany, Italian province Gorizia, and counties in the Upper Rhine valley (cf. BRICHETTI \& FRACASSO 20 i i, DWenger i 995, SAmWald i996, WestermanN et al. 2006). Regions in NE Slovenia held densities within the range of those in adjacent districts across the border (SAMWALD 1996). However, in regions influenced by oceanic climate like the Northwest German Plain and Great Britain, but also Finland and some southern countries, large-scale densities can be several times higher. In most of the occupied $10 \mathrm{~km}$ UTM squares in Bulgaria several tens of pairs breed; exceptionally, their numbers reach over 1000 pairs/square (GLUTZ vON BLOTZHEIM \& BAUER I993, Fraissinet et al. 1997, ANTIKAINEN I999, BAUER et al. 2005, VASILEV et al. 2007, VELEVSKi et al. 2010 , GEDEON et al. 2014). In Slovenia, Jackdaws selected all main nest site types characteristic of the species, with the majority using buildings as reported elsewhere. Several intriguing results emerged: (1) nesting in trees was restricted to NE Slovenia, and (2) cliff-nesting was very rare. Compared to neighbouring Austria, both types are underrepresented in terms of site/pair numbers as well as distribution. There, tree nesters constituted $20 \%$ of all pairs and were registered in seven out of nine federal states. However, the proportion of treenesters in NE Slovenia is remarkably high and actually very similar to adjacent Oststeirisches Hügelland (c. 50\%) (Dvorak 1996, Samwald 1996). Therefore, this geographically uniform, transboundary territory designates a stronghold of tree-nesting Jackdaws in the wider region. It seems that predominance of treenesting in Central Europe is often restricted to smaller parts of the breeding range. This is typical also of Germany and Switzerland where, although inferior to selection of buildings in general, tree-nesters can

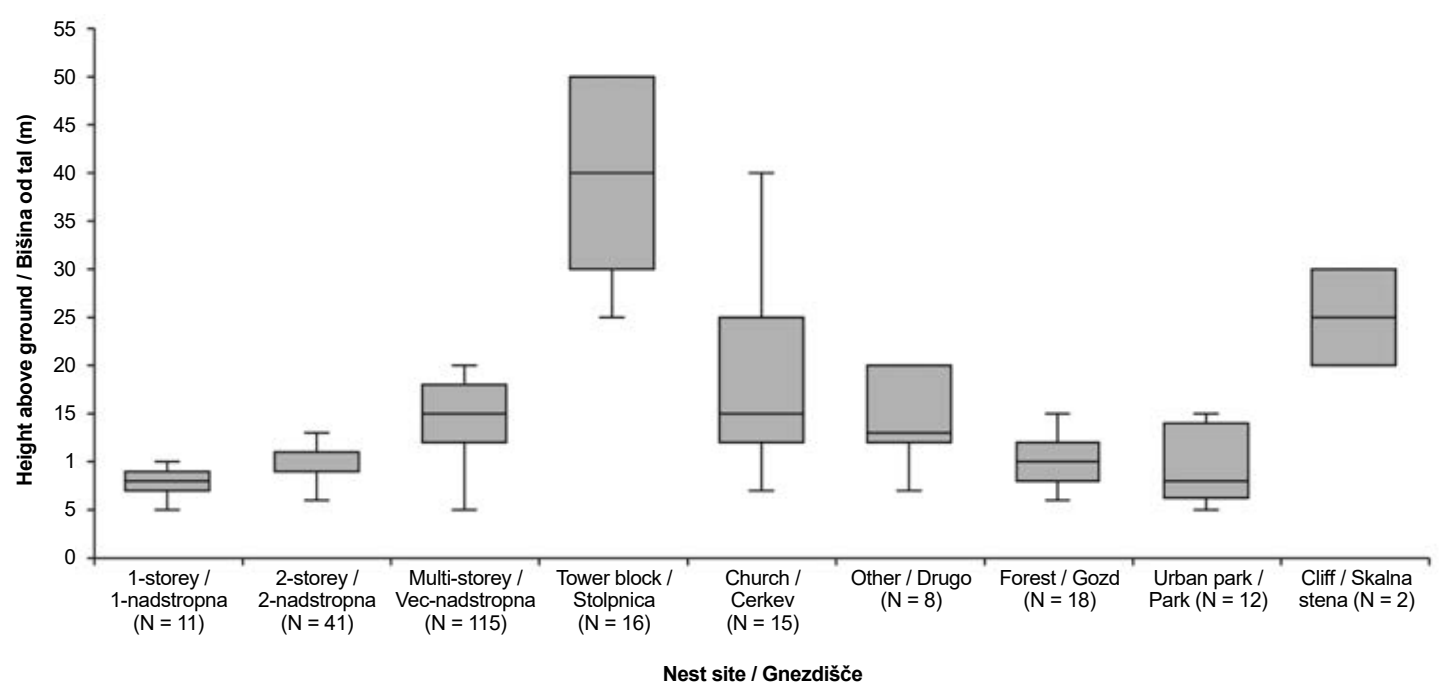

Figure 11: Height of Jackdaw Corvus monedula nests above ground at different nest sites in Slovenia in 2008-2011 (N = 238)

Slika 11: Višina gnezd kavke Corvus monedula od tal na različnih gnezdiščih v Sloveniji v letih 2008-2011 (N = 238) 
regionally constitute up to $60 \%$ of all pairs, e.g. in Hessen and the canton of Bern, or even more, e.g. in the canton of Geneva (VOGEL 1990, BECKER 2002). The reason for such restricted range of tree-nesting in Slovenia is not clear. We can argue that a lack of suitable nest sites is not the limiting factor as Black Woodpecker Dryocopus martius, practically the only hole-providing species for Jackdaws nesting in forests, is numerous and widespread, being absent from only a few $10 \mathrm{~km}$ UTM squares (NOAGS database). The same was observed in Germany (Hoffman 2005) and probably holds true for other countries as well. However, several points might be important here (cf. Johnsson et al. 1993, RUDOLPH 2000): (1) Jackdaws nested only close to the forest edge; (2) breeding colonies occurred mainly in stands with clusters of nest holes and taking into account not all holes excavated are suitable for various reasons, this essentially limits potential nest sites to old forest sections with abundant mature trees; (3) distance to foraging grounds, i.e. Jackdaws prefer open areas usually within several hundred metres from nests (STREBEL I99I, GLUTZ VON Blotzheim \& Bauer 1993, KNeUbüHL I998, UNGER \& KURTH 20I0). Based on these assumptions we can infer that favourable conditions for treenesting are indeed found only in hilly regions of NE Slovenia like Slovenske gorice and Goričko, where the majority of forest-nesting pairs was recorded. Here, open agricultural areas interspersed with small beechforest islands form mosaic-like countryside with a total forest area of c. 30\% (PERKo \& OROžEn AdAMič 1999), corresponding to descriptions of habitat in

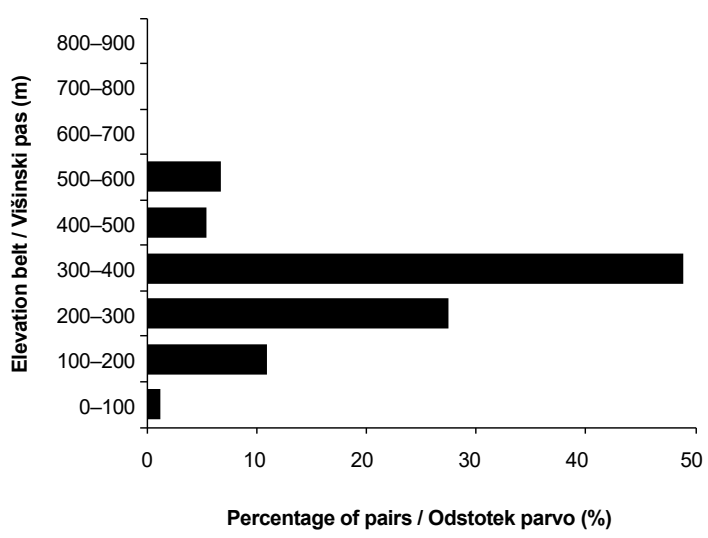

Figure 12: Elevational distribution of Jackdaw Corvus monedula pairs in Slovenia in 2008-2011

Slika 12: Višinska razširjenost parov kavke Corvus monedula v Sloveniji v letih 2008-2011 different regions of Europe with prevailing tree-nesters (Johnsson 1994, SAmwald 1996, Rudolph 2000). Although tree-nesting is usually rather uncommon in European cities (DWENGer 1995, SALVATI et al. 2002, WeSTERMANN et al. 2006, CZECHOWSKI et al. 2013, HoI-LeITNER et al. 2016), it is nevertheless surprising that it was not recorded at all in any of the largest cities of Slovenia, despite seemingly suitable trees available in parks and avenues. Nonetheless, it must be emphasized that tree nesting is scarce in many European regions or even entire countries (e.g. HANDRINOS \& AKRIOTIS i 997, Westermann et al. 2006, VAsilev et al. 2007). Presumably, in more urbanized areas Jackdaws may prefer buildings to trees if these provide abundant nest holes for reasons such as predator avoidance, proximity of suitable foraging sites and affinity for colonial nesting (GLUTZ VON BlotZHEIM \& BAUER I993, Salvati 2002A, SalVati et al. 2002).

The question arises when Jackdaw began nesting on buildings in settlements in Slovenia. Historically, it was described as a tree-nesting species (SEIDENSACHER i 860, REISER 1925). However, bell towers and attics are already mentioned as favoured nesting places for colonies in the pre-World War 2 literature (PonEbŠEK \& PONEBŠEK 1934). Later, nesting in tall buildings, churches and attics is also described (KREČIČ \& ŚUŠTERŠIČ I 963). For NE Slovenia, VOGRIN (1998) presumed that colonization of settlements started only after WW2. Indeed, it seems likely that a major shift in nest site selection must have occurred in this period which gave rise to intensive urbanization and construction of many previously unknown building types, nowadays favoured by Jackdaws (e.g. tower blocks) (cf. MeLIK I963). Regarding cliff-nesting, the situation is rather unexpected in Slovenia, given the apparently high availability of potential nest sites, notably in the alpine and Mediterranean regions. However, most sites in the alpine region are located in narrow valleys, areas dominated by extensive forest tracts or high elevations and hence unsuitable for Jackdaws. In Mediterranean regions, forests cover most of the area nowadays due to progressive overgrowing of grasslands, following widespread land abandonment in the past (IvAjNšič et al. 2013).

Ranking of average colony size per nest site type in this study corresponds to the findings in Austria and Switzerland, while average figures (nest site types and overall) are fairly similar to the latter and smaller than in the former (Vogel I990, DvoraK 1996). The most prominent difference is the absence of very large cliff-nesting colonies in Slovenia. In both countries mentioned above some of these qualify among the largest on a national level, with several tens of pairs 
(two or three in Austria with > 100 pairs). Regarding building-nesters, the situation is more similar in general, with our largest colonies comparable in size (e.g. largest in Austria c. 120 pairs, Switzerland in recent times 43, formerly c. 100 pairs). The proportion of solitary-pair sites was substantially lower (DVORAK 1996, Brader \& Samhaber 2005, Maumary et al. 2007), but the difference can probably be at least partly explained by the higher number of undetected solitary pairs in forests of NE Slovenia. In Vienna, a similarly low proportion of solitary pairs was partly explained by sufficient possibilities for colonial nesting on buildings (Hoi-Leitner et al. 20I6). However, small average colony size on buildings, well below values considered as optimal colony size by ANTIKAINEN (1987), does not corroborate this assertion for Slovenia. Low number of colonies with $>30$ pairs as found in Slovenia seems typical of the majority of Central Europe (VOGEL i 990, DWenger i995, SAMWALd i996, SALVATi et al. 2002, WeSTERMANN et al. 2006). Jackdaw colony size is mainly influenced by the availability of nest sites, but also foraging sites, and evidence exists that other factors such as predator interference might be important, too (GLUTZ Von BLOTZHEIM \& BAUER I993, SALVATi $e t$ al. 2002). Highest numbers tend to occur in places where many potential nest sites are adjacent to favourable foraging sites (FRAISSINET et al. 1997), as was the case for the majority of the largest colonies found during this study. Therefore, small size of tree-nesting colonies is characteristic, resulting in low breeding densities in regions with a predominance of tree-nesters (RUDOLPH 2000, this study) and consequences affecting breeding success such as increased predation (JoHNSSON 1994). However, some notable exceptions to this rule can be found in Central Europe, e.g. with tree-nesting colonies of 30-60 pairs in Upper Austria (BRADER \& SAMHABER 2005) and > 200 pairs in NE Poland (CHMielewski 2015).

All Jackdaws recorded used cavities for nesting. No open-nesting in abandoned nests of other crows or dense canopies of conifers as occasionally reported was observed. The former is hardly surprising owing to the scarcity of Rook Corvus frugilegus colonies in Slovenia (NOAGS database) with which Jackdaws most often associate (RöEL 1978, GLUTZ VON BLOTZHEIM \& Bauer 1993, Gorman 1996, Westermann et al. 2006). Furthermore, Jackdaws were not found nesting in quarries, bridges and various technical facilities frequently described elsewhere (e.g. Dvorak 1996, Westermann et al. 2006, Kostin 2009). Although multi-storey residential buildings were the most important by proportion of nesting pairs, tower blocks and churches hosted a higher number of pairs per building on average. The former was most evident in Kranj where two large colonies were centred around a few 9-11 storey tower blocks. However, the highest number of pairs on a single building (19 and 17) was recorded for multi-storey residential buildings with large footprints, thus offering numerous nest sites along the outer walls. Nevertheless, most of the largest colonies extended over large areas $\left(\geq 1 \mathrm{~km}^{2}\right)$, where pairs nested on numerous nearby buildings, often interspersed with unused sections of the built-up area, as observed for example in Vienna (HOI-LeITNER et al. 2016) and rural settlement in the Netherlands (RöEL 1978). The proportion of pairs using one- and twostorey residential buildings was rather low as these are smaller and obviously have fewer (potential) nest sites. This is especially true for one-storey buildings, exclusively represented in this study by single-family houses, where single pairs per house were almost the rule as found by RöEL (1978). Here, nesting was exclusively associated with chimney pots. Overall, fewer than $40 \%$ of chimney-nesting pairs occurred on buildings other than one- and two-storey, most notably a colony of nine pairs in a single large chimney of a hotel at Bled. On the whole, both these nest site subtypes and nesting in chimney pots were rare outside Dravsko polje in the Podravje region. Such restricted utilisation of chimney pots appears unusual given their widespread use in Austria (registered in most districts, prevailing in two and Vienna) as well as many other areas in Europe (RöEL 1978, DvoraK 1996, SAMWALD i 996, Fraissinet et al. 1997, Brader \& SAMHABER 2005, Westermann et al. 2006, VAsilev et al. 2007 , Hoi-Leitner et al. 2016). One conceivable explanation for such a situation is that chimney pots in Slovenia are generally unfavourable for nesting as c. $75 \%$ of dwellings use sources of heating that require functional chimneys (STATistical Office RS 2002). As a matter of fact, several authors report Jackdaws only use chimneys that are abandoned or seldom used (ANTIKAINEN I 999, Hoi-Leitner et al. 2016). At Dravsko polje, however, Jackdaws mostly nested in functional chimney pots. The reason for their predominance and obviously long tradition here, i.e. $72 \%$ of pairs nested in chimney pots already years ago (VoGRIN I998), could possibly arise from a combination of high breeding site-fidelity/ natal philopatry of the species (SCHMIDT I999A) and a lack of other potential nest sites in the area. Contrary to these assertions, VoGRIN (1998) observed that Jackdaws supposedly favoured chimney pots, as these were occupied earlier than attics, possibly due to their inaccessibility to predators. Among nest hole placements, roofs and other structures situated in the uppermost parts of buildings predominated. Thus, 
height of nests above ground varied greatly, largely reflecting features of building subtypes and supposedly also the preference of Jackdaws for selecting the highest holes, the fact often attributed to competition for nest sites with other species (e.g. Feral Pigeon Columba livia f. domestica that tends to occupy lower holes), predation pressure and human disturbance (ANTIKAINEN 1987, SALVATI 2002A, BAUER et al. 2005). It seems that the proportion of potentially available nest holes is highest along different edges of roofs and roof/outer wall junctions, as these sections are probably more prone to damage.

The majority of nests on trees were placed in holes, the only exception being a few pairs nesting in cavities in plane trees, formed on the spot where a branch was broken or cut off, either vertically or horizontally to the ground. Several forest colonies (up to 5 pairs) were situated in single beech trees with multiple holes at different heights, as observed also in Germany (RUDOLPH 2000). It was judged that nearly all holes in beech trees used by Jackdaws were excavated by Black Woodpecker and the range of heights above ground $(6-15 \mathrm{~m})$ found corresponded to value given for this species (GLUTZ von BLOTZHEIM \& BAUER I 994). A similar predominance of plane trees in pairs nesting in urban parks/avenues was reported for Vienna, for which several possible explanations were offered. These include effective predator protection enabled by its smooth bark and their effective reaction to damage, keeping the entrance to the nest hole small. Nevertheless, the fact that some plane species rank among the most widespread large ornamental trees that often have large number of suitable nesting holes should not be neglected (TORELLI 2004, Hoi-LEITNER et al. 2016). During this study, nesting was not recorded in traditional orchards, occasionally used by solitary pairs and small colonies in the 1980s. Tree species reported there were apple tree Malus domestica and Common Walnut Juglans regia (VogRIN I998, F. BRAČKO in litt.).

The altitudinal distribution confirmed the Jackdaw's status of a typical lowland species. In the years prior to this study it was found higher at a handful of sites in the Upper Sava Valley (e.g. Belca at c. $690 \mathrm{~m}$ a.s.l.) and on the Bloke Plateau (720 m a.s.l.), but breeding was not confirmed. The highest breeding season record is from a mountain pasture above Tolmin at c. $800 \mathrm{~m}$ a.s.l. (PERUŠEK 1994) where actual nesting is unlikely. This is broadly in line with the findings in Austria where $>90 \%$ of nest sites lie below $700 \mathrm{~m}$ and only few can be found higher than $900 \mathrm{~m}$ a.s.l. (DvORAK 1996). In Italy, Jackdaw is widespread up to $700-800 \mathrm{~m}$, less frequent up to $1000 \mathrm{~m}$ and very locally up to $1500 \mathrm{~m}$ a.s.l. or even higher (BRICHETTI \& FRACASSO 20I I), while in Germany the highest nest sites are situated at c. $800 \mathrm{~m}$ a.s.l. (GEDEON et al. 2014). Most of the nest sites in Switzerland are under $800 \mathrm{~m}$, but the species penetrates deep into the Alps along the valleys with favourable climate, reaching over $1400 \mathrm{~m}$ a.s.l. (MaUmary et al. 2007).

Despite the lack of comprehensive data on the species' past numbers and trends, there is little doubt that the population declined significantly over the previous two or three decades. Firm evidence of the disappearance of the species and its colonies a few dozen of sites, together with the depletion of several formerly large colonies, support this assertion. If only sites with known numbers are taken into consideration that would constitute a decline of $24 \%$ in c. $10-20$ years to reach the situation presented in this study. Given the known distribution in the 1980s (GEISTER I995), with numerous nowadays unoccupied $10 \mathrm{~km}$ UTM squares for which no exact past records were obtained in this study (e.g. western border area, eastern part of Podravje region etc.) and a fairly high number of past colonies with unknown size, the magnitude of the decline must have been substantially larger. Still, some care is needed in the interpretation of these figures as it is unknown to what extent pairs from abandoned colonies might move to new sites, recorded during this study. Circumstantial evidence for such events exists for few sites (i.e. number of pairs in existing colonies increased/ new ones appeared immediately after the abandonment of nearby sites). It is known that Jackdaws can readily occupy alternative nest sites if available close enough and at a suitable distance to foraging sites, regardless of high breeding site-fidelity (TöPFER I 999, EISERMANN \& BÖrner 2006, Hoi-LeitNer et al. 2016). However, for certain regions with good datasets from different periods like Dravsko and Ptujsko polje, a population decline of at least $40 \%$ is certain, with the majority occurring during the first half of the 1990s. A similar rate of decline over the past 20 years is suspected for (parts) of Austrian Styria (AlbegGer et al. 20 I 5). With large declines also reported in Hungary (BIRDLife INTERNATIONAL 2015), this indicates an unfavourable population status in the wider region. Some local/ regional increases beyond the time period covered in this study (e.g. breeding population in Slovene Istria was in the range of 50-60 pairs in 2014-2016, NOAGS database; population of Goričko in far NE Slovenia was estimated at very high 100-200 pairs, although underlying data hardly support this, DENAC \& KMECL 2014) were probably offset by local declines/extinctions on the other hand (c. 20-30 pairs lost in NE Slovenia in the last few years, own data), without major impact 
on overall long-term negative trend. According to the IUCN criteria (IUCN 20I2A, 20I2B, IUCN 2016), Jackdaw would qualify as Vulnerable (VU) on the Red List of Slovenia based on A2 criteria (An estimated population size reduction of $\geq 30 \%$ over the last three generations, where the reduction or its causes may not have ceased, based on direct observation/a decline in area of occupancy, and influence of immigration being unknown).

The commonest known cause of decline is renovation of buildings that affected some sizeable colonies, notably on churches. Despite their relative importance, separate studies found most churches in Slovenia unsuitable for nesting of birds (including Jackdaw) due to closing of their openings and human disturbance (Tome 1986, DenaC et al. 2002). Random post-2011 observations demonstrate a further aggravation: recently two colonies (Črenšovci, Kotlje) became extinct after renovation of the nave's roof and installation of window protection grids on the bell tower (Ž. Šalamun, M. PodgoreleC pers. comm.). Restoration works on buildings are regularly referred to as the main cause of extinction of colonies, often leading to abrupt, catastrophic regional/local population declines (EISERMANN \& BÖRNER 2006, Westermann et al. 2006). One of the most alarming potential threats for building-nesting Jackdaws in Slovenia is the dependence of many colonies (including some of the largest in country) on the old socialist-style tower blocks and multi-storey buildings constructed in the 1960s and 1970s with an abundance of suitable nest holes. The quality of living in such densely populated residential neighbourhoods has become an important issue in modern urban planning and calls for their complete renovation have emerged (e.g. the Planina housing district of Kranj, holding colony of 40 pairs). Consequently, massive losses/reductions of these nest sites can be predicted in the near future. Installation of nest boxes is often suggested as an appropriate conservation measure, with examples of several-fold population increases available (e.g. BÖRNER \& EISERMANN 1999). In Slovenia, however, recent attempts gave rather mixed results, ranging from local increase to complete non-acceptance of nest boxes despite destruction of former nest sites nearby and an obvious lack of alternatives. Little is known about threats affecting tree-nesting pairs, but modern forestry practices are generally not in favour of large holenesting birds. One of the current concerns is increased annual timber harvest in Slovene forests, especially in deciduous forests (DENAC \& MiHelič 20I5), probably reducing the proportion of mature beech trees suitable for nesting of Jackdaws, too. The proportion of extinct cliff-nesting colonies is striking. Apart from the Sava gorge where causes seem straightforward, their extinction from karst limestone walls of SW Slovenia is more obscure. The following explanations seem plausible: (1) Lack of suitable foraging areas at appropriate distance due to progressive overgrowing of grasslands, recognized as a major conservation issue in the region (IVAJNšıč et al. 2013) (see above). This phenomenon might be responsible also for disappearance of the species from the entire Karst plateau (cf. GeISTER I995). (2) Human disturbance due to expansion of rock climbing in the cliffs with nesting Jackdaws, as often mentioned among threats in literature although with little tangible evidence (VOGEL I990, WAGNER I 994, BAUER et al. 2005). In the study of cliff-nesting birds of Kraški rob escarpment, Jackdaw was considered an adaptable species, less affected by this activity compared to some other specialised cliff-nesters (MARČETA 1994). (3) Competition with other species using cliffs for nesting in the area given like Eagle Owl Bubo bubo and Peregrine Falcon Falco peregrinus (cf. WAGNer 2006). Populations of both species increased substantially in Slovenia in the last two decades (Birdlife InTERNATIONAL 2004, DeNAC et al. 201 I). Quality of foraging sites is considered an important factor influencing breeding success of Jackdaws (STrebel i991, KNeUbüHL 1998), while conversion of high-quality meadows and pastures into arable fields can presumably lead to food shortage, resulting in extinction of colonies (SAMWALD 1996). Given the widespread overall decline of grassland areas in Slovenia (KMECL et al. 2014), this threat is likely to be important for Jackdaw, among others. Finally, the attitude of the general public towards the species is mostly negative for reasons such as allegedly untidy nesting in buildings, clogging of chimney pots with nesting material, noisy behaviour and damage in agriculture (e.g. on crops and round bale silage). Without targeted conservation of existing nest sites/ nest holes and restoration of most important former sites, supported by a provision of suitable foraging sites and campaigns to raise awareness, the future prospects of the Jackdaw in Slovenia seems grim.

Acknowledgements: I am indebted to the following people without whom the implementation of country-wide census would be impossible or information about the past and present occurrence of Jackdaws in Slovenia incomplete: Dominik Bombek, Dejan Bordjan, Tanja Börc, Franc Bračko, Alenka Bradač, Igor Brajnik, Damijan Denac, Dušan Dimnik, Andreja Dremelj, Katica Drndelič, Dare Fekonja, Sandra Forjanič, Matej Gamser, Peter Grošelj, Jurij Gulič, Magdalena Habets, Jurij 
Hanžel, Tomaž Jančar, Jernej Jorgačevski, Martin Kavka, Andrej Kelbič, Matjaž Kerček, Tjaša Kerček, Dušan Klenovšek, Urška Koce, Ivan Kogovšek†, Ivica Kogovšek, Igor Kovše, Jože Kozamernik, Aljaž Kožuh, Peter Krečič, Anže Kristan, Borut Kumar, Tina Leskošek, Katja Logar, Marjan Logar, Marjanca Mandeljc, Cvetka Marhold, Katja Markovič, Janez Maroša, Tomaž Mihelič, Alenka Mrakovčič, Sava Osole, Jožef Osredkar, Alen Ploj, Miha Podlogar, Slavko Polak, Maja Potokar, Matjaž Premzl, Aleksander Pritekelj, Špela Pulko, Tomaž Remžgar, Borut Rubinić, Marko Sameja, Urška Satler, Mirko Silan, Andreja Slameršek, Mateja Soklič, Nataša Šalaja, Iztok Škornik, Tatjana Škrabec Confidenti, Anže Škoberne, Simon Širca, Metka Štok, Tanja Šumrada, Aleš Tomažičc, Gregor Torkar, Tone Trebar, Marjan Trobec, Peter Trontelj, Martina Trup, Vesna Trup, Zlata Vahčič, Andrej Valenti, Franc Verovnik, Jani Vidmar, Nuša Virnik, Željko Šalamun, Miha Žnidaršič. Vojko Havliček helped with census coordination in Central Slovenia.

\section{Povzetek}

Leta 2008 smo opravili koordiniran popis kavke Corvus monedula, da bi ocenili njeno gnezdečo populacijo, razširjenost in izbiro gnezditvenih mest $\mathrm{v}$ Sloveniji. Zbiranje podatkov za nepopisana območja smo nadaljevali še v obdobju 2009-2011, vključno $s$ podatki o nekdanjih kolonijah in dejavnikih ogrožanja. Skupno smo zabeležili 663-794 parov kavk na 86 lokacijah, gnezdečo populacijo ocenjujemo na 700-900 parov. Več kot tretjina parov je bila ugotovljena v osrednji Sloveniji, posebno v Ljubljani $(20,8 \%)$, skoraj četrtina pa v Podravju. Večina kolonij je štela 2-5 parov, največja je bila za Bežigradom v Ljubljani z 82-87 pari. Gostota na večjih območjih je bila od 0,15 para $/ 10 \mathrm{~km}^{2} \mathrm{v}$ goratih območjih v severni Sloveniji do 3,65 para $/ 10 \mathrm{~km}^{2}$ na Savski ravni. Večina kavk (82,2 \% parov) je gnezdila na stavbah, medtem ko je bilo gnezdenje na drevesih redkejše (14,7 \%) in skoraj izključno omejeno na vzhodno Slovenijo. Gnezdenje v skalnih stenah je bilo ugotovljeno le na dveh krajih v Slovenski Istri (3,1\%). Povprečna velikost kolonije se je pomembno razlikovala glede na tip gnezdišča: kolonije v skalnih stenah so bile v povprečju največje (mediana 9,5 para), sledile so jim kolonije na stavbah (6) in drevesih (3). Izmed parov, gnezdečih na stavbah, jih je bilo največ na večstanovanjskih stavbah $(34,2 \%)$, pomembni deleži pa tudi na cerkvah $(14,4 \%)$ in stanovanjskih blokih (13,5\%). Največ parov je gnezdilo v luknjah v strehah (26,9\%), pod napušči $(18,0 \%)$ in $\mathrm{v}$ dimnikih (14,7\%). Pari, gnezdeči na drevesih, so bili ugotovljeni predvsem $\mathrm{v}$ majhnih gozdovih $\mathrm{v}$ odprti kulturni krajini. Največ gozdnih kolonij, 14 od 16, je bilo na bukvah Fagus sylvatica (53,1 \% parov). Kavke, ki so gnezdile v mestnih parkih in drevoredih, so uporabljale predvsem platane Platanus sp. $(30,6 \%$ parov). Velika večina kavk gnezdi v nižinah, $88,1 \%$ parov je bilo popisanih na nadmorskih višinah pod $400 \mathrm{~m}$ n. v., najviše gnezdeča kolonija pa je bila zabeležena na $578 \mathrm{~m} \mathrm{n}$. v. V preteklosti so se kavke pojavljale na najmanj 54 dodatnih lokacijah, vendar je njihovo število tam močno upadlo ali pa so do obdobja raziskave celo izumrle. Populacijski upad na teh lokacijah ocenjujemo na 217-254 parov, kar pomeni 24-odstotni upad v 10-20 letih. Upoštevajoč kriterije IUCN bi kavko na Rdečem seznamu uvrstili med ranljive vrste (VU). Najpogostejši znani vzrok upada je obnova stavb - grožnja, ki se bo v prihodnje le še povečevala.

\section{References}

Albegger E., Samwald O., Pfeifhofer H. W., Zinko S., Ringert J., Kolleritsch P., Tiefenbach M., Neger C., Feldner J., Brandner J., Samwald F. \& Stani W. (201 5): Avifauna Steiermark. Die Vögel der Steiermark. Birdlife Österreich - Landesgruppe Steiermark, Leykam Buchverlags Ges. m. b. H. Nfg. \& Co. KG, Graz.

Antikainen E. (1987): Correlation between height and site distribution of nest holes occupied by Jackdaws Corvus monedula Linnaeus, 1758, in Poland. - Acta Zoologica Cracoviensia 30: 11-24.

Antikainen E. (1980): The breeding success of the Jackdaw Corvus modedula in nesting cells. - Ornis Fennica 58 (2): $72-77$.

Antikainen E. (1999): Effects of protection on the population dynamics of the Jackdaw (Corvus monedula) in Finland. - Mitteilungen des Vereins Sächsischer Ornithologen 8, Sonderheft 2: 9-20.

Arnold K. E., Griffiths R. (2003): Sex-Specific Hatching Order, Growth Rates and Fledging Success in Jackdaws Corvus monedula. - Journal of Avian Biology 34 (3): 275-281.

Bauer H.-G., Bezzel E., Fiedler W. (eds.) (2005): Das Kompendium der Vögel Mitteleuropas. - AULA Verlag, Wiebelsheim.

Becker P., Becker S. F. (2002): Ergebnisse der DohlenErfassung (Corvus monedula spermologus) in Hessen 2000. - Vogel und Umwelt 13 (1):3-9.

Bibič A., Janžekovič F. (1986): Ptiči Veržeja in okolice. Acrocephalus 10 (41/42): 45-50.

Biondo M. (1998): Intraspezifische Aggressionen, Populations- und Nahrungsökologie der Dohle Corvus monedula in Murten, Kanton Freiburg. - Ornithologische Beobachter 95 (3): 203-220.

BirdLIFE INTERNATIONAL (2004): Birds in Europe: population estimates, trends and conservation status. BirdLife Conservation Series No. 12. - BirdLife International, Cambridge. 
BirdLife InTERnATIONAL (2015): Corvus monedula (Eurasian Jackdaw). European Red List of Birds. - Office for Official Publications of the European Communities, Luxembourg.

BIRDLIFE INTERNATIONAL (2016): Species factsheet, Eurasian Jackdaw Corvus monedula. - [http://www.birdlife.org], 05/10/2016.

BÖRnER J., EISERMANN K. (I999): Ergebnisse des Artenschutzprojektes für die Dohle (Corvus monedula) in der Region Chemnitz 1991-1997. - Mitteilungen des Vereins Sächsischer Ornithologen 8, Sonderheft 2: 21-33.

BRAČKo F. (1997): Ornitološki atlas Drave od Maribora do Ptuja (1989-1992). - Acrocephalus 18 (82): 57-97.

Brader M., SAmhaber J. (2003): Bestandserfassung der Dohle (Corvus monedula) in Oberösterreich - Bericht über die Brutsaison 2003 - Vogelkundliche Nachrichten aus Oberösterreich, Naturschutz aktuell 11 (1/2): 41-61.

Brader M., Samhaber J. (2005): Bestandserfassung der Dohle (Corvus monedula) in Oberösterreich. - Bericht über die Brutsaison 2004 (mit Nachträgen aus 2003) Vogelkundliche Nachrichten aus Oberösterreich, Naturschutz aktuell 13 (1): 33-60.

Brichetti P., Fracasso G. (201 i): Ornitologia Italiana. Identificazione, Distribuzione, Consistenza e Movimenti degli Uccelli Italiani. Volume 7. Paridae-Corvidae. Oasi Alberto Perdisa Editore, Bologna.

Chmielewski C. (2015): Observations of Jackdaws Corvus monedula Robbing Nests. - International Studies on Sparrows 39 (1): 28-31.

Cramp S., Perrins C. M. (eds.) (1994): Handbook of the birds of Europe, the Middle East and North Africa. The birds of the Western Palearctic. Volume 8. Crows to Finches. - Oxford University Press, Oxford.

Czechowski P., Bocheński M., Ciebiera O. (2013): Decline of Jackdaws Corvus monedula in the city of Zielona Góra. - International Studies on Sparrows 37 (1): 32-36.

Davidson G. L., Clayton N. S., Thornton A. (2014): Salient eyes deter conspecific nest intruders in wild Jackdaws (Corvus monedula). - Biology Letters 10 (2): $1-4$.

del Hoyo J., Elliott A., Christie D. A. (eds.) (2009): Handbook of the Birds of the World. Volume 14. Bush-shrikes to Old World Sparrows. - Lynx Edicions, Barcelona.

Denac D., Marčič M., Radolič P., Tomažıč A. (2002): Sove v cerkvah, gradovih in drugih objektih na območju Vipavske doline in Krasa v JZ Sloveniji. - Acrocephalus 23 (112): 91-95.

Denac K, Kmecl P. (2014): Ptice Goričkega. - DOPPS, Ljubljana.

Denac K., Minelič T. (2015): Status in varstvo belohrbtega detla Dendrocopos leucotos v Sloveniji. - Acrocephalus 36 (164/165): 5-20.

Denac K., Mihelič T., Božič L., KMecl P., Jančar T., Figelj J., Rubinić B. (20 I I): Strokovni predlog za revizijo posebnih območij varstva (SPA) z uporabo najnovejših kriterijev za določitev mednarodno pomembnih območij za ptice (IBA). Končno poročilo (dopolnjena verzija). DOPPS, Ljubljana.
DvoraK M. (1996): Verbreitung und Bestand der Dohle (Corvus monedula) in Österreich in den Jahren 1993 und 1994. Studienbericht 2. - BirdLife Österreich, Wien.

Dvorak M., Ranner A., Berg H.-M. (1993): Atlas der Brutvögel Österreichs. - Umweltbundesamt, Wien.

Dwenger R. (1995): Die Dohle. - Westarp Wissenschaften, Magdeburg.

EBCC (2016): Trends of common birds in Europe, 2016 update. - [http://www.ebcc.info/index.php?ID=612], $05 / 10 / 2016$.

EISERMANN K., BöRner J. (2006): Populationsökologie und Auswirkungen von Manipulationen des Nistplatzangebotes an einer Brutkolonie der Dohle (Corvus monedula) in Chemnitz. - Mitteilungen des Vereins Sächsischer Ornithologen 9: 611-622.

Fowler J., Cohen L. (1996): Statistics for ornithologists. BTO Guide No. 22. Second edition. - British Trust for Ornithology.

Fraissinet M., Henderson I., Mastronardi D. (1997): Jackdaw Corvus monedula. pp. 680-681 In: HAgEMEIJER W. J. M., BlaIR M. J. (eds.): The EBCC Atlas of European Breeding Birds: Their Distribution and Abundance. - T \& A D Poyser, London.

Gedeon K., Grüneberg C., Mitschke A., Sudfeldt C., Eickhorst W., Fischer S., Flade M., Frick S., Geiersberger I., Koop B., Kramer M., KrÜger T., Roth N., Ryslavy T., Stübing S., Sudmann S. R., STEFFEns R., VÖKLER F., WITt, K. (20I4): Atlas Deutscher Brutvogelarten - Atlas of German Breeding Birds. Stiftung Vogelmonitoring und dem Dachverband Deutscher Avifaunisten, Münster.

GeISTER I. (I995): Ornitološki atlas Slovenije. Razširjenost gnezdilk. - DZS, Ljubljana.

Gill F., Donsker D. (eds) (2016): IOC World Bird List (v 6.3). doi: 10.14344/IOC.ML.6.3. - [http://www. worldbirdnames.org], 05/10/2016.

Glutz von Blotzheim U., BAuer K. (1993): Handbuch der Vögel Mitteleuropas. Band 13/III, Passeriformes (4. Teil). - AULA Verlag, Wiesbaden.

Glutz von Blotzheim U., Bauer K. (1994): Handbuch der Vögel Mitteleuropas. Band 9, ColumbiformesPiciformes. - AULA Verlag, Wiesbaden.

Gorman G. (1996): The Birds of Hungary. - Helm (A \& C Black), London.

Gregori J. (1992): Ptiči hrastovega pragozda in bližnje okolice v Krakovskem gozdu. - Acrocephalus 13 (52): 66-75.

GsChwandtner W. (2005): Die Dohle Corvus monedula in Nordtirol/Österreich. Bestandserhebung in den Jahren 2004 und 2005. - Monticola 9: 299-318.

Hagemeijer W. J. M., Blair M. J. (eds.) (i997): The EBCC Atlas of European Breeding Birds: Their Distribution and Abundance. - T \& A D Poyser, London.

Handrinos G., Akriotis T. (1997): The Birds of Greece. Helm (A \& C Black), London.

HoffmanN, M. (2005): Der Schwarzspecht (Dryocopus martius) im Burgwald - Bestandsentwicklung, Brutbaumauswahl und Höhlenanlage. - Vogel und Umwelt 16: 67-91. 
Hoi-Leitner M., Wiedenegger E., Hille, S. (2016): Status der Dohle (Corvus monedula) und ihr Nistplatzschutz in Wien. - Vogelwarte 54 (2): 73-81.

IUCN (2012A): IUCN Red List Categories and Criteria: Version 3.1. Second edition. - IUCN, Gland \& Cambridge.

IUCN (2012B): Guidelines for Application of IUCN Red List Criteria at Regional and National Levels: Version 4.0. - IUCN, Gland \& Cambridge.

IUCN (2016): The IUCN Red List of Threatened Species, Version 2016-2: Corvus monedula. - [http://www. iucnredlist.org/details/22705929/1], 05/11/2016.

IVAJNŠIČ D., KALIGARIČ M., ŠKORNIK S. (2013): Spremembe rabe tal med leti 1830 in 2008 na območju Movraškega Krasa in na bližnjih flišnih predelih. - Revija za geografijo 8 (1): 83-96.

JanČART., TrebušAK M. (2000): Ptice Kozjanskega regijskega parka. - Acrocephalus 21 (100): 107-134.

JoHnsson K. (1994): Colonial breeding and nest predation in the Jackdaw Corvus monedula using old Black Woodpecker Dryocopus martius holes. - Ibis 136 (3): 313-317.

Johnsson K., Nilsson S. G., TJernberG M. (1993): Characteristics and utilization of old Black Woodpecker Dryocopus martius holes by hole-nesting species. - Ibis 135 (4): 410-416.

Kmecl P., Jančar T., Mihelič T. (20I4): Spremembe v avifavni Kozjanskega parka med letoma 1999 in 2010: velik upad števila travniških ptic. - Acrocephalus 35 (162/163): 125-138.

KNEUbüHL M. (1998): Nahrungsangebot und Raumnutzung der Dohle Corvus monedula bei Murten, Kanton Freiburg. - Ornithologische Beobachter 95 (3): 221-244.

Kostin P. (2009): Kolonija čavki Corvus monedula u postrojenjima za vađenje nafte kod Elmira. - Ciconia 18: 232.

Kubitza R., Bugnyar T., Schwab C. (2015): Pair bond characteristics and maintenance in free-flying jackdaws Corvus monedula: effects of social context and season. Journal of Avian Biology 46 (2): 206-215.

LORENZ K. (193I): Beiträge zur Ethologie sozialer Corviden. - Journal für Ornithologie 79 (1): 67-120.

MarČEta B. (1994): Stanje in ogroženost gnezdilcev sten črnokalskega Kraškega roba. - Annales, Series Historia Naturalis 4: 43-51.

Matvejev S. D., Vasić, V. F. (I973): Catalogus faunae jugoslaviae. Aves lV/3. - SAZU, Ljubljana.

Maumary L., Vallotton L., Knaus P. (2007): Die Vögel der Schweiz. - Schweizerische Vogelwarte, Sempach \& Nos Oiseaux, Montmollin.

Melık A. (1963): Slovenija. Geografski opis. I. Splošni del. Druga, predelana izdaja. - Slovenska matica, Ljubljana.

Model N. (1996): Zur Verbreitung, Bestandsentwicklung, Brutbiologie, Gefährdung und zum Schutz der Dohle (Corvus monedula) im Main-Kinzig-Kreis (Hessen). Vogel und Umwelt 8: 305-313.

OFFEREINS R. (2003): Identification of eastern subspecies of Western Jackdaw and occurrence in the Netherlands. Dutch Birding 25 (4): 209-220.

Perko D., Orožen AdAmič M. (1 999): Slovenija. Pokrajine in ljudje. - Mladinska knjiga, Ljubljana.

Perušex M (1994): Sršenar Pernis apivorus. - Acrocephalus $15(65 / 66): 151$.
PonebšEk J., PonebšEk B. (1934): Gnezdilci Slovenije. - I. Izvestje Ornitološkega observatorija v Ljubljani 19261933: $37-60$.

Plut D. (1999): Regionalizacija Slovenije po sonaravnih kriterijih. - Geografski vestnik 71: 9-25.

Reiser O. (1925): Die Vögel von Marburg an der Drau. Natuwissenschaftlicher Verein in Steiermark, Graz.

Riggenbach H. E. (1979): Die Dohle Corvus monedula in der Schweiz. - Ornithologische Beobachter 76 (4): 153-168.

RöEll A. (1978): Social Behaviour of the Jackdaw, Corvus monedula, in Relation to its Niche. - Behaviour 64 (1/2): $1-124$.

RudolpH B.-U. (2000): Baumbrütende Dohlen Corvus monedula im Inn-Chiemsee-Hügelland (Südbayern). Ornithologische Anzeiger 39: 207-215.

Salvati L. (2002A): Nest Site and Breeding Habitat Characteristics in Urban Jackdaws Corvus monedula in Rome (Italy). - Acta Ornithologica 37 (1): 15-19.

Salvati L. (2002B): Census area and Jackdaw (Corvus monedula) density in rural and urban habitats of Europe. - Aquila 107/108: 47-53.

SAlvati L., Manganaro A., FATTORINi S. (2002): Breeding density, colony size, and colony spacing in relation to nest sites in an urban Jackdaw Corvus monedula population. Larus 48: 39-45.

SAMWALD O. (1996): Brutverbreitung und Bestand 1993/1994 der Dohle (Corvus monedula) in der Steiermark (Aves) - Mitteilungen der Abteilung für Zoologie am Landesmuseum Joanneum Graz 50: 35-48.

Schmidt K. (1988): Die Dohle (Corvus monedula) als Brutvogel im Bezirk Suhl (DDR) und erste Erfahrungen zum Schutz dieser gefährdeten Vogelart. - Beihefte $\mathrm{zu}$ den Veröffentlichungen für Naturschutz und Landschaftspflege in Baden-Württemberg 53: 191-2010.

Schмidт K. (I 999A): Zugverhalten und Populationsökologie derDohle(Corvusmonedula) nach Beringungsergebnissen aus Südwest-Thüringen. - Mitteilungen des Vereins Sächsischer Ornithologen 8, Sonderheft 2: 41-53.

Schмidт K. (1999B): Mehrjährige Beobachtungen an einem Krähen-Dohlen-Schlafplatz in Bad Salzungen, SüdwestThüringen. - Mitteilungen des Vereins Sächsischer Ornithologen 8, Sonderheft 2: 77-93.

Schwab C., Bugnyar T., Kotrschal K. (2008): Preferential learning from non-affiliated individuals in jackdaws (Corvus monedula). - Behavioural Processes 79 (3): 148-155.

SEIDENSACHer E. ( I 860): Erscheinungen in der Vogelwelt bei Neustadtl in Krain, vom Monat November 1858 bis zum Sommer 1859. - Journal für Ornithologie 8 (4): 311-319.

SMOLE J. (2000): Kavka, ptica leta 2000. - Svet ptic 6 (1): $20-21$.

SOLER M., SOLER J. J. (1993): Does the risk of nest predation affect clutch size in the Jackdaw Corvus monedula? - Bird Study 40 (3): 232-235.

Sovinc A. (1990): Ptice doline Drage pri Igu (Ljubljansko barje, Slovenija) v letih $1978-88$ in naravovarstvena vprašanja. - Varstvo narave 16: 101-118.

Statistical Office of the Republic of Slovenia (2002): Census of Population, Households and Housing Dwellings by main source of heating. - [http://pxweb. stat.si/pxweb/Dialog/statfile2.asp], 23/10/2016. 
Strebel S. (I99I): Bruterfolg und Nahrungsökologie der Dohle Corvus monedula im Schloss Murten FR. Ornithologische Beobachter 88 (3): 217-242.

ŠEHIČ D., ŠEHIĆ D., ŠEHIĆ M. (20IO): Geografski atlas Slovenije. - Geodetska uprava Republike Slovenije, Geološki zavod Slovenije \& DZS, Ljubljana.

ŠKORNIK I. (20I2): Favnistični in ekološki pregled ptic Sečoveljskih solin. - Soline pridelava soli, Seča.

ŠTumberger B. (2003): Kavka Corvus monedula. Acrocephalus 24 (117): 78.

Tоме D. (1986): Cerkev - pribežališče za sove? Acrocephalus 7 (30): 53-55.

Tome D., Sovinc A., Trontelj P. (2005): Ptice Ljubljanskega barja. Monografija DOPPS št. 3. - DOPPS, Ljubljana.

Torelli N. (2004): Platana (Platanus sp.) - les, skorja in kulturna zgodovina. - Les (Ljubljana) 56 (10): 321-328.

TÖPfER T. (1999): Veränderungen im Bestand und in der Brutplatzwahl der Dohle (Corvus monedula) in Dresden. - Mitteilungen des Vereins Sächsischer Ornithologen 8, Sonderheft 2: 71-74.

UNGER C., KURTH K. (2010): Untersuchungen zur Brutbiologie und zur Habitatwahl bei der Dohle Coloeus monedula im Landkreis Hildburghausen, Südthüringen. - Anzeiger des Vereins Thüringer Ornithologen 7: 95-107.

Unger C., Peter H.-U. (2002): Elterliches Investment der Dohle Corvus monedula bei der Jungenaufzucht. Vogelwelt 123: 55-64.

Vasilev V., Stoynov E., Kutsarov I., Ferdinandova V. (2007): (Eurasian) Jackdaw Corvus monedula. pp. 582-583 In: Iankov P. (ed.): Atlas of Breeding Birds in Bulgaria. Conservation Series, Book 10. - Bulgarian Society for the Protection of Birds BSPB, Sofia.

Velevski M., Hallmann B., Grubač B., Lisičanec T., Stoynov E., Lisičanec E., Avukatov V., Božič L., ŠTUMBERGER B. (20I0): Important Bird Areas in Macedonia: Sites of Global and European Importance. Acrocephalus 31 (147): 181-282.

Vogel C. (1990): Brutverbreitung und Bestand 1989 der Dohle Corvus monedula in der Schweiz. Ornithologische Beobachter 87 (3): 185-208.

Vogrin M. (1998): Gnezditev kavke Corvus monedula na Dravskem polju. - Falco 13/14: 57-60.

Wagner S. (1994): Alle Felsenbrutplätze der Dohle (Corvus monedula) im Bezirk Villach, Kärnten, erloschen. Egretta 37 (1): 34-35.

Wagner S. (2006): Dohle Corvus monedula. pp. 328-329 In: Feldner J., Rass P., Petutschnig W., Wagner S., Malle G., Buschenreiter R. K., Wiedner P., Probst R.: Avifauna Kärntens. Band 1. Die Brutvögel. Naturwissenschaftlicher Verein für Kärnten, Klagenfurt.

WestermanN K., Andris K., BOSchert M., Matz W., Münch C., Opitz H., Peter D., Schneider F. (2006): Brutverbreitung, Brutbestand, Nistplätze, Rückgangsursachen und Schutz der Dohle (Corvus monedula) am rechtsrheinischen südlichen Oberrhein. Naturschutz am südlichen Oberrhein 4: 129-150.

ZGS (20II): Gozdnatost Slovenije. - [http://www.zgs.si/ fileadmin/zgs/main/img/CE/gozdovi_SLO /Karte/ Gozdnatost_KO.jpg], 18/10/2016.
Zimmermann D. (I95I): Das Brutvorkommen der Dohle, Coloeus monedula, in der Schweiz. - Ornithologische Beobachter 48 (1): 15-33.

Prispelo / Arrived: 6. 11.2016

Sprejeto / Accepted: 29. 1.2017 